\title{
Host-Targeting Agents to Prevent and Cure Hepatitis C Virus Infection
}

\author{
Mirjam B. Zeisel ${ }^{1,2, *}$, Emilie Crouchet ${ }^{1,2}$, Thomas F. Baumert ${ }^{1,2,3}$ and Catherine Schuster ${ }^{1,2, *}$ \\ Received: 25 September 2015 ; Accepted: 19 October 2015 ; Published: 2 November 2015 \\ Academic Editor: Eric O. Freed \\ 1 Inserm, U1110, Institut de Recherche sur les Maladies Virales et Hépatiques, 67000 Strasbourg, France; \\ emilie.crouchet@etu.unistra.fr (E.C.); thomas.baumert@unistra.fr (T.F.B.) \\ 2 Université de Strasbourg, 67000 Strasbourg, France \\ 3 Institut Hospitalo-Universitaire, Pôle Hépato-digestif, Hôpitaux Universitaires de Strasbourg, \\ 67000 Strasbourg, France \\ * Correspondence: mirjam.zeisel@unistra.fr (M.B.Z.); catherine.schuster@unistra.fr (C.S.); \\ Tel.: +33-3-68-85-37-03; Fax: +33-3-68-85-55-08
}

\begin{abstract}
Chronic hepatitis $\mathrm{C}$ virus (HCV) infection is a major cause of liver cirrhosis and hepatocellular carcinoma (HCC) which are leading indications of liver transplantation (LT). To date, there is no vaccine to prevent HCV infection and LT is invariably followed by infection of the liver graft. Within the past years, direct-acting antivirals (DAAs) have had a major impact on the management of chronic hepatitis $C$, which has become a curable disease in the majority of DAA-treated patients. In contrast to DAAs that target viral proteins, host-targeting agents (HTAs) interfere with cellular factors involved in the viral life cycle. By acting through a complementary mechanism of action and by exhibiting a generally higher barrier to resistance, HTAs offer a prospective option to prevent and treat viral resistance. Indeed, given their complementary mechanism of action, HTAs and DAAs can act in a synergistic manner to reduce viral loads. This review summarizes the different classes of HTAs against HCV infection that are in preclinical or clinical development and highlights their potential to prevent $\mathrm{HCV}$ infection, e.g., following LT, and to tailor combination treatments to cure chronic $\mathrm{HCV}$ infection.
\end{abstract}

Keywords: hepatitis C virus; host-targeting agent; direct-acting antiviral; viral resistance

\section{Introduction}

Hepatitis $\mathrm{C}$ virus (HCV) is a hepatotropic enveloped RNA virus of the Flaviviridae family. It is a highly variable virus that has been classified into six major genotypes [1]. Approximately 170 million individuals worldwide are infected by HCV. Chronically HCV-infected individuals are at risk for developing cirrhosis and hepatocellular carcinoma (HCC) which are major indications for liver transplantation (LT). There is no vaccine to prevent HCV infection and, until recently, antiviral therapy (based on pegylated (PEG) interferon (IFN) alpha and ribavirin) only enabled a cure for less than half of the patients, with strong differences in treatment outcome depending on the genotype. Within the past years, with the sequential approval of novel antivirals specifically targeting viral proteins (direct-acting antivirals (DAAs)), chronic hepatitis $C$ has become a curable disease in the majority of treated patients and the most recent DAAs act in a pan-genotypic manner (reviewed in [2]). Several novel antivirals are in late-stage clinical development and will further broaden the therapeutic arsenal against $\mathrm{HCV}$ and enable the tailoring of combination treatments for distinct patient groups.

Antivirals can be classified into two distinct categories depending on whether they target viral proteins, i.e., DAAs, or interfere with cellular factors involved in viral infection, i.e., host-targeting 
agents (HTAs). For many years, HCV-host interactions have remained largely elusive due to the lack of robust model systems, and anti-HCV drug development has paralleled discoveries about the molecular mechanisms of viral replication. Indeed, the establishment of increasingly sophisticated model systems to study HCV infection (reviewed in [3-5]) has enabled researchers to characterize the molecular mechanisms underlying the HCV life cycle in great detail (reviewed in [6-9]) and to design a wide variety of antivirals targeting various steps of the viral replication cycle (reviewed in $[8,10]$ ). While several HTAs had been developed to characterize the HCV replication cycle and corroborate the importance of defined host factors for distinct steps of viral infection, others have been uncovered through functional screening approaches aimed at repurposing existing small molecules/approved drugs [11-13]. This review summarizes the different classes of HTAs against HCV infection and highlights their potential for antiviral therapy to prevent viral resistance.

\section{HTAs to Inhibit Various Steps of the HCV Life Cycle}

The HCV life cycle can be subdivided into five different steps, including viral entry, viral translation, viral replication, viral assembly, and release of new virions. Each of these steps requires defined virus-host interactions to ultimately enable the virus to establish chronic infection. Given the amount of host factors involved in the HCV life cycle, this review solely focuses on some of these host factors that have been suggested to represent potential targets for HTAs during distinct steps of the HCV life cycle within hepatocytes (Figure 1). Other compounds exhibiting a broader mechanism of action by modulating the host's immune responses, also termed biological response modifiers (Table 1), such as IFNs, Toll-like receptor (TLR) 7, or TLR9 agonists [14-17], are not reviewed in detail here.

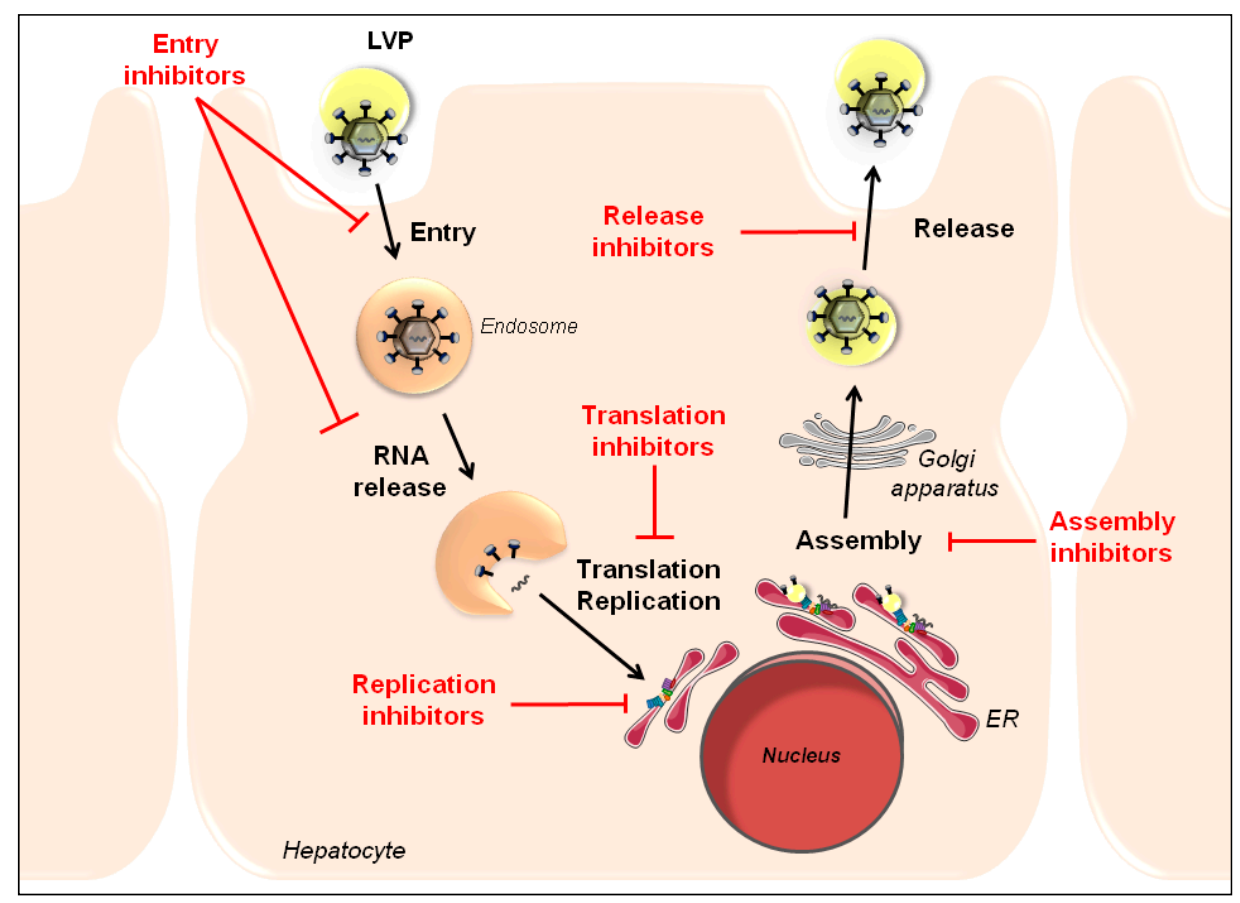

Figure 1. Schematic representation of the hepatitis $\mathrm{C}$ virus (HCV) life cycle and targets for antiviral therapy. HCV interacts with the basolateral membrane of hepatocytes, resulting in viral entry into the host cell. The virus is internalized via endocytosis and translation of the HCV RNA occurs in the cytoplasm following viral fusion and uncoating. Viral replication takes place within the cytoplasm in perinuclear endoplasmic reticulum (ER)-derived membranes called the "membranous web". Progeny virions are assembled on cytosolic lipid droplets and subsequently transported along the secretory pathway and maturated in the Golgi before their release through microtubular transport and endocytic recycling compartment. Targets for antiviral therapy are highlighted in red. 
Table 1. Stage of development of host-targeting agents (HTAs) for prevention and/or treatment of $\mathrm{HCV}$ infection. Only HTAs having at least reached in vivo preclinical development are listed.

\begin{tabular}{|c|c|c|c|c|}
\hline Category & Target & Compounds & Stage of Development & References \\
\hline \multirow{8}{*}{$\begin{array}{c}\text { Entry } \\
\text { inhibitors }\end{array}$} & CD81 & $\mathrm{mAbs}$ & Mouse model & [18] \\
\hline & \multirow{2}{*}{ SR-BI } & $\mathrm{mAbs}$ & Mouse model & [19-21] \\
\hline & & ITX-5061 & Phase 1 & {$[22,23]$} \\
\hline & CLDN1 & $\mathrm{mAbs}$ & Mouse model & {$[24]$} \\
\hline & EGFR & Erlotinib & Phase $1 / 2$ & NCT01835938 \\
\hline & NPC1L1 & Ezetimide & Mouse model & [25] \\
\hline & \multirow{2}{*}{ Endocytosis/fusion } & Silymarin/silibinin & Phase $2 / 3$ & {$[26,27]$} \\
\hline & & Chloroquine & Phase 4 & NCT02058173 \\
\hline $\begin{array}{l}\text { Translation } \\
\text { inhibitors }\end{array}$ & miR-122 & Miravirsen & Phase 2 & {$[28,29]$} \\
\hline \multirow{5}{*}{$\begin{array}{l}\text { Replication } \\
\text { inhibitors }\end{array}$} & miR-122 & Miravirsen & Phase 2 & {$[28,29]$} \\
\hline & HMGCoA reductase & Statins & Phase 3 & {$[30,31]$} \\
\hline & \multirow{3}{*}{ Cyclophilin } & Alisporivir & Phase $2 / 3$ & [32] \\
\hline & & SCY-635 & Phase 2 & [33] \\
\hline & & NIM811 & Phase 2 & {$[34]$} \\
\hline \multirow{5}{*}{$\begin{array}{l}\text { Assembly } \\
\text { inhibitors }\end{array}$} & $\alpha$-glucosidase 1 & Celgosivir & Phase 2 & [35] \\
\hline & DGAT-1 & LCQ908 & Phase 2 & NCT01387958 \\
\hline & Cyclophilin & NIM811 & Phase 2 & [34] \\
\hline & $\operatorname{PPAR} \alpha$ & Naringenin & Phase 1 & [36] \\
\hline & $\mathrm{HNF} 4 \alpha$ & Bezafibrate & Phase 4 & [37] \\
\hline \multirow{6}{*}{$\begin{array}{c}\text { Biological } \\
\text { response modifiers }\end{array}$} & \multirow{6}{*}{ Immune responses } & IFN- $\alpha$ & FDA-approved & www.hcvguidelines.org \\
\hline & & IFN- $\lambda$ & Phase 3 & NCT01795911 \\
\hline & & TLR7 agonist & Phase 1 & {$[15,16]$} \\
\hline & & TLR9 agonist & Phase 3 & [17] \\
\hline & & Thymosin $\alpha 1$ & Phase 3 & [38] \\
\hline & & Nitazoxanide & Phase 2 & {$[39,40]$} \\
\hline
\end{tabular}

mAbs: monoclonal antibodies, EGFR: epidermal growth factor receptor; IFN : interferon; TLR : Toll-like receptor; CLDN1: claudin 1; CD81 : cluster of differentiation 81; SR-BI: scavenger receptor class B type I; NPC1L1: Niemann-Pick C1-Like 1; HMGCoA: 3-hydroxy-3-methylglutaryl-coenzyme A; DGAT-1: diacylglycerol O-acyltransferase 1; PPAR $\alpha$ : peroxisome proliferator-activated receptor alpha; HNF4 $\alpha$ : hepatocyte nuclear factor 4 alpha. FDA: Food and Drug Administration; miR-122: microRNA-122

\subsection{Entry Inhibitors to Prevent Initiation of Viral Infection and Viral Dissemination}

The HCV entry process has been particularly well characterized within the past years (for a review see [6]). The initial viral attachment on the hepatocyte cell surface is believed to involve the interaction of the viral particle with heparan sulfate proteoglycans (HSPGs) [41-46], particularly with syndecan 1 (SDC1) [47] and syndecan 4 (SDC4) [48], low density lipoprotein receptor (LDLR) [49-53], and scavenger receptor class B type I (SR-BI) [54-59]. Interestingly, both viral (HCV envelope glycoproteins) and host-derived (apolipoproteins) factors within the viral particle appear to mediate this process (reviewed in $[6,60]$ ). Thus, the very first steps of viral interaction with the host cell surface can be inhibited by targeting host factors expressed either on the viral particle or on the host cell membrane (Figure 2). Indeed, it has been shown that synthetic anti-lipopolysaccharide peptides that bind to heparan sulfate moieties on the cell surface as well as antibodies directed against SR-BI or LDLR inhibit HCV attachment/infection [53,59,61]. Likewise, peptides that mimic the receptor binding domain and the HSPG binding domain of apolipoprotein E (apoE) inhibit HCV infection $[45,48]$ and antibodies directed against apoE $[45,62,63]$ as well as preincubation of recombinant cell culture-derived HCV (HCVcc) with soluble LDLR have also been shown to neutralize HCV infection, likely at the attachment/entry level $[53,64]$. Recently, it has been suggested that low-molecular-weight lignin, a component of Lentinula edodes mycelia solid culture 
extract, that has been reported to exhibit hepatoprotective activity, might inhibit HCV attachment through binding to apoE on the viral particle [65] given the structural similarity between lignin sulfate and heparan sulfate [66]. Interestingly, lipoprotein lipase (LPL) increases HCV attachment to the target cell by bridging virus-associated lipoproteins and cell surface heparan sulfate, whereas antibodies as well as a small molecule inhibitor-targeting LDLR have been shown to decrease HCV uptake $[67,68]$. In addition to its bridging function, LPL has been shown to inhibit viral entry by immobilizing the virus at the cell surface $[64,69]$. Most recently, it has been shown that very low-density lipoprotein (VLDL) is a serum component that inhibits HCV attachment [70].

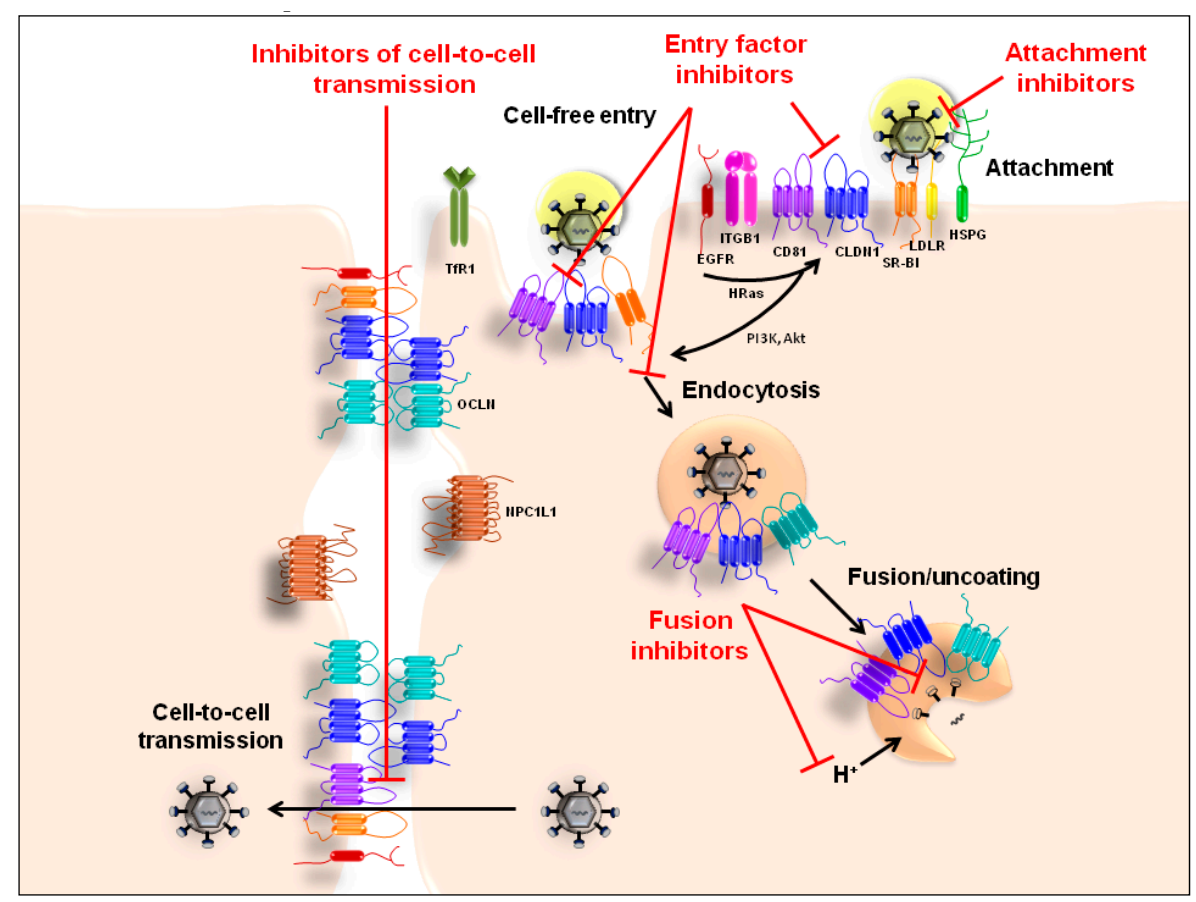

Figure 2. Schematic representation of HCV entry. The initial viral attachment on the basolateral membrane of hepatocytes is believed to involve the interaction of the viral particle-both viral (HCV envelope glycoproteins) and host-derived (apolipoproteins) factors-with HSPGs (heparan sulfate proteoglycans), LDLR (low density lipoprotein receptor) and SR-BI (scavenger receptor class B type I). Following interaction between the virus and different host factors expressed at the hepatocyte cell surface, including CD81 (cluster of differentiation 81) and CLDN1 (claudin 1), as well as rearrangement of cell surface proteins, the virus is ultimately internalized into its host cell via clathrin-mediated endocytosis. Additional host factors, including EGFR (epidermal growth factor receptor), NPC1L1 (Niemann-Pick C1-like 1) and TfR1 (transferrin receptor 1), contribute to the HCV entry process, for example by modulating intracellular signaling pathways or endocytosis. Following acidification of the endosome and subsequent fusion of viral and endosomal membranes, the viral genome is released into the cytoplasm. In addition to cell-free virus entry, HCV has also been described to transmit between hepatocytes through direct cell-to-cell transmission involving CD81, SR-BI, CLDN1, OCLN (occludin), EGFR, EphA2 (ephrin receptor A2) and NPC1L1. HTAs can interfere with different steps of the HCV entry process as highlighted in red.

Following initial attachment to the hepatocyte basolateral membrane, the virus interacts with additional host factors expressed at the hepatocyte cell surface to ultimately enter its host cell via clathrin-mediated endocytosis. It is believed that the interaction of the HCV envelope glycoproteins E1 and E2 with SR-BI, CD81, CLDN1 and potentially OCLN plays a major role in this process and some of these host factors have thus been suggested to play the role of "HCV receptors" [54,71-75]. Cluster of differentiation 63 (CD63) may also directly interact with HCV E2 and contribute to $\mathrm{HCV}$ entry [76]. Of note, additional host factors, termed "co-factors", including various kinases, 
e.g., epidermal growth factor receptor (EGFR), ephrin receptor A2 (EphA2), AP-2-associated protein kinase 1 and cyclin G-associated kinase (GAK), as well as Niemann-Pick C1-like 1 (NPC1L1) and transferrin receptor 1 (TfR1), also contribute to the $\mathrm{HCV}$ entry process, for example by modulating intracellular signaling pathways or endocytosis [25,77-79]. Indeed, downstream EGFR signaling pathways including the GTPase Harvey rat sarcoma viral oncogene homolog (HRas) have been shown to be required for HCV entry, particularly for the formation of the CD81-CLDN1 co-receptor complex that is essential for this process (reviewed in [80]). Thus, HCV entry can be efficiently inhibited using antibodies, peptides or other molecules binding to SR-BI, CD81, CLDN1, EGFR and TfR1 as well as small molecule inhibitors of EGFR, EphA2, GAK, NPC1L1 and HRas [25,77,78,81-96] (Figure 2). Furthermore, host antiviral immune responses may also contribute to inhibiting HCV entry by interfering with the viral entry process as demonstrated by the inhibition of the EGFR kinase activity and, consequently, CD81-CLDN1 co-receptor formation via induction of IFN- $\alpha$ inducible protein 6 (IFI6), an IFN-stimulated gene (ISG) [97].

Following internalization via clathrin-mediated endocytosis, the viral genome is released into the cytoplasm after fusion of viral and endosomal membranes. In addition to some of the compounds described above, HCV endocytosis and/or fusion can be efficiently perturbed using amphipathic DNA polymers and small molecules including two anti-malaria drugs (chloroquine, ferroquine), arbidol and sylimarin/silibinin [98-103] (Figure 2). Of note, in addition to its interference with HCV entry, silymarin/silibinin-derived compounds and chloroquine have also been reported to interfere with viral replication $[100,104,105]$.

In addition to cell-free virus entry, HCV has been shown to also directly infect neighboring hepatocytes via a process called cell-to-cell transmission [106-108]. In contrast to the cell-free HCV entry described above, HCV cell-to-cell transmission is resistant to most of the neutralizing antibodies described so far and is thus believed to play a major role in the maintenance of chronic infection. Although the detailed molecular mechanisms remain to be uncovered, it has been reported that the HCV envelope glycoproteins and apoE on the virus particle as well as CD81, SR-BI, CLDN1, OCLN, EGFR, EphA2 and NPC1L1 on the host cell play an important role for cell-to-cell transmission $[19,24,25,77,92,106-108]$ (Figure 2). Of note, it has been described that HCV can circumvent CD81 and SR-BI for this process [108,109]. However, the potential consequences for antiviral therapy targeting entry factors remain unknown (also see Section 3 below). Notably, viral variants that appear not to require SR-BI for their in vitro infectivity remain sensitive to SR-BI-specific antibodies in vivo, as demonstrated using the human liver-chimeric uPA-SCID mouse model [20].

Host-targeting entry inhibitors (HTEIs) including antibodies directed against host entry factors or co-factors as well as small molecule inhibitors have proven to efficiently prevent/delay HCV infection in the human liver-chimeric uPA-SCID mouse model $[18,24,25,99,110,111]$, and, thus, may represent a valuable strategy to prevent liver graft infection following LT. Furthermore, they may also contribute to treatment of chronic hepatitis $C$ since an antibody targeting CLDN1 has recently been shown to cure chronic HCV infection in human liver-chimeric uPA-SCID mice in the absence of detectable toxicity [24]. Finally, their combination with other HTAs and/or DAAs can result in a synergistic antiviral activity [21], which provides perspectives for novel combination therapies for the cure of chronic hepatitis $C$ (also see Section 3 below). Collectively, these data highlight the potential of HTEIs not only for prevention of HCV infection, e.g., during LT, but also for treatment of chronic hepatitis $C$. Of note, a phase $1 / 2$ clinical trial evaluating erlotinib, a clinically licensed EGFR inhibitor used in cancer therapy, has been initiated in chronic HCV patients (https://clinicaltrials.gov/; Identifier: NCT01835938). Furthermore, silymarin/silibinin-derived compounds have been evaluated in phase $2 / 3$ clinical trials and (case) reports suggest their efficacy in decreasing viral loads in chronic HCV patients and prevention of hepatitis $C$ recurrence after LT, although other studies reported viral rebounds [26,112-115]. Whether this potential effect is (partially) due to silymarin/silibinin's interference with viral entry remains to be defined. While the efficacy of chloroquine for treatment of non-response $\mathrm{HCV}$ patients is currently being evaluated 
in a phase 4 clinical trial (https://clinicaltrials.gov/; Identifier: NCT02058173), no clinical trial of ferroquine in hepatitis $C$ patients has been registered so far.

\subsection{Translation Inhibitors to Prevent Subsequent Viral Replication}

Following viral endocytosis and fusion, HCV RNA is translated in an internal ribosome entry site (IRES)-mediated manner. The highly conserved IRES is located in the $5^{\prime}$-untranslated region (5'-UTR) of the viral genome $[116,117]$. HCV can thus directly recruit the translation initiation complex to the viral RNA to trigger viral protein translation via a cap-independent mechanism. The HCV IRES binding to the $40 \mathrm{~S}$ ribosomal subunit is independent of canonical or non-canonical initiation factors. Moreover, HCV translation initiation only requires eukaryotic initiation factors (eIF) eIF2, eIF3 and eIF5 [118,119]. In contrast, optimal IRES activity is supported by the recruitment of several host proteins named IRES transacting factors (ITAFs) (for a review, see [7]), which represent a novel target for therapeutic intervention. Indeed, a synthetic peptide corresponding to the $\mathrm{N}$-terminal 18 amino acids of the La antigen (efficiently blocks HCV translation by binding and sequestering other ITAFs [120].

IRES-ribosome interaction has been shown to be mediated through the binding of the $40 \mathrm{~S}$ subunit to the stem loop III, domain e and f (SLIIIef), of the HCV IRES. A recent study demonstrated that a small RNA mimicking the SLIIIef domain (SLRef) selectively inhibits HCV translation by retaining the ability to interact with the $40 S$ subunit. Interestingly, in line with previous studies, it was shown that the anti-HCV activity of SLRef could be mainly due to interaction and sequestration of the La antigen [121]. Ribosome-HCV IRES association can also be disturbed by prostaglandin A1 (PGA1) which exhibits dose-dependent inhibitory effects on HCV translation [122]. Indeed, its antiviral effect occurs through PGA1/eIF3-40S subunit/HCV IRES RNA complex formation which inhibits HCV IRES-mediated translation. Furthermore, repetitive PGA1 treatment appears to be safe in cell culture [122]. The in vivo efficacy of molecules interfering with HCV IRES-ribosome association remains to be determined.

Furthermore, microRNA-122 (miR-122) plays an important role in HCV translation. MiR-122, one of the most abundant liver-expressed miRNAs, binds to the HCV genome and enhances viral translation and replication [123,124]. Sequestering miR-122 using miravirsen, a locked nucleic acid-modified oligonucleotide complementary to the $5^{\prime}$-end of miR-122, showed prolonged and dose-dependent reduction in HCV viremia in patients without evidence of long-term safety issues [28,29] (also see Section 2.4 below).

Recently, the receptor for activated C kinase 1 (RACK1), a component of the ribosomal $40 \mathrm{~S}$ subunit [125,126], was identified as an essential factor for HCV IRES-mediated translation [127]. Interestingly, RACK1 is not required for the classical cap-dependent translation and inhibition of RACK1 expression in cell culture models did not reveal major toxicity [127]. Thus, the development of RACK1 inhibitors may be an attractive perspective for future anti-HCV therapy.

\subsection{Replication Inhibitors to Inhibit Viral Genome Amplification}

Following translation and cleavage of the $\mathrm{HCV}$ polyprotein, the viral replicase complex, composed of HCV non-structural (NS) proteins, NS3, NS4A, NS4B, NS5A and NS5B, is assembled. HCV replication is a highly coordinated process involving host factors in addition to the replicase complex. Several functional small interfering RNA (siRNA) and chemical screens have been performed to uncover host factors involved in HCV replication and have provided useful insights into this process [128-135].

HCV has been demonstrated to remodel intracellular membranes, including endoplasmic reticulum (ER) membranes, for its replication and this process takes place at the so-called "membranous web" [136]. Indeed, HCV NS proteins induce the formation of double-membrane vesicles [136-139]. It has been suggested that this process may be linked to the activation of the autophagy pathway [140], a cellular catabolic process where protein aggregates and damaged 
organelles are removed for recycling. Indeed, several studies suggested that HCV activates the autophagic pathway to support its replication (reviewed in [141,142]). Moreover, HCV replication has been reported to occur on autophagosomal membranes $[140,143]$. This may enable the virus to conceal its RNA and evade double-stranded RNA-triggered host antiviral responses [140]. Chloroquine has been described as an inhibitor of autophagic protein degradation and, in addition to inhibiting HCV entry by modulating endosomal acidification [98], chloroquine has been shown to reduce HCV replication [105]. Host proteins have also been reported to contribute to the formation of double-membrane vesicles (reviewed in [144]), e.g., cyclophilin A (CypA), which interacts with NS5A, and proline-serine-threonine phosphatase interacting protein 2 (PSTPIP2), which interacts with NS4B and NS5A $[145,146]$. The importance of CypA for the HCV life cycle has recently been underscored in a humanized mouse model of HCV infection in which the Ppia gene had been knocked out [147]. In addition to CypA, several other cyclophilins (Cyps) have been reported to also contribute to HCV replication [128,148-150]. Cyclosporines are classical Cyp inhibitors; however, their immunosuppressive properties preclude their use as antivirals. Within the past years, several alternative Cyp inhibitors have been generated: cyclosporine A (CsA) derivatives without immunosuppressive properties and new molecules structurally unrelated to CsA (reviewed in [151]). Cyp inhibitors were the first class of HTAs against HCV reaching clinical development. Three non-immunosuppressive Cyp inhibitors have so far demonstrated clinical efficacy in chronic hepatitis C patients in IFN-based as well as IFN-free treatment regimens [32,151]. These Cyp inhibitors have been shown to disrupt/prevent the formation of CypA-NS5A complexes and thereby inhibit HCV replication [33,151-154]. In addition, the anti-HCV activity of CypA inhibitors may be increased since they appear to restore the host innate immune responses to HCV [33].

NS5A is a central player within the membranous web as it interacts with a plethora of host factors, thereby orchestrating viral replication. The lipid kinase phosphatidyl-inositol-4-kinase III alpha (PI4KIII $\alpha$ ) is one of the major NS5A partners in this process [155]. Indeed, NS5A binds to and activates PI4KIII $\alpha$ and this, in turn, regulates the phosphorylation status of NS5A [156]. PI4KIII $\alpha$ activity leads to phosphatidyl-inositol-4-phosphate (PI4P) accumulation within the membranous web and likely the subsequent recruitment of cellular lipid transporters leading to the modulation of its lipid content (reviewed in [144]). In the absence of PI4KIII $\alpha$ activity or through alteration of its interaction with NS5A, changes in the ultrastructural morphology of the membranous HCV replication complex were observed $[132,155,156]$. PI4KIII $\beta$ has also been reported to contribute to the replication of HCV genotype 1 but not genotype 2 [157,158]. PI4KIII inhibitors able to reduce HCV replication in vitro have been developed, but their in vivo toxicity as well as the lethal phenotype of transgenic mice exhibiting kinase-defective PI4KIII $\alpha$ preclude their further clinical development as antivirals [134,158-161]. As stated above, the host cell lipid metabolism plays an important role in the HCV replication complex [162]. Particularly elements of cholesterol and fatty acid synthesis and geranylgeranylation of host proteins have been shown to modulate viral replication. Indeed, several genes involved in lipid metabolism have been reported to be modulated during acute HCV infection of chimpanzees [163]. HCV replication can be disrupted in vitro by treatment with inhibitors of 3-hydroxy-3-methylglutaryl CoA (HMGCoA) reductase or with an inhibitor of protein geranylgeranyl transferase I [164,165]. Notably, not all HMGCoA reductase inhibitors affect $\mathrm{HCV}$ replication, suggesting the existence of a different structure-activity relationship between the anti-HMGCoA reductase activity and the antiviral activity [166]. Fluvastatin is a statin that has been reported to increase the efficacy of IFN-based treatment in chronic HCV-infected patients $[30,31,167,168]$. Recent in vitro studies have provided novel insights into the mechanism of action of fluvastatin. The anti-HCV effect of fluvastatin has been suggested to be due to the induction of microtubule bundling and a decrease of expression of the microtubule binding partner doublecortin-like kinase 1 (DCLK1) [169]. Furthermore, fluvastatin and other statins exhibiting an antiviral effect against HCV induce the expression of heme oxygenase- 1 (HO-1), which has been reported to reduce HCV replication [170-173]. HMGCoA reductase activity can 
also be inhibited using SKI-1/S1P inhibitors [174,175]. In addition to inhibiting HCV replication, SKI-1/S1P inhibitors may also reduce the production of new virions [174]. Interestingly, it has also been reported that antibody-mediated blocking of the LDLR leads to an increase in the ratio of phosphatidylethanolamine to phosphatidylcholine in host cells and a decrease in HCV replication [64], further strengthening the link between lipid metabolism and HCV replication. Moreover, a functional chemical compound screen identified the estrogen receptor alpha (ESR $\alpha)$ as an interaction partner of NS5B within lipid rafts on ER membranes [176]. Indeed, tamoxifen, a partial ESR agonist and prototype selective estrogen-receptor modulator, as well as a decoy peptide against ESR $\alpha$-NS5B interaction inhibited HCV replication and ESR $\alpha$-NS5B interaction in the replicase complex [176]. ESR $\alpha$ may thus also represent a potential target for anti-HCV therapy. Finally, it has been recently reported that HCV replication can also be inhibited by cholesterol-25-hydroxylase (CH25H) whose expression is increased upon HCV infection [177-179]. $\mathrm{CH} 25 \mathrm{H}$ synthesizes 25 -hydroxycholesterol $(25 \mathrm{HC})$ which displays antiviral activities against different enveloped viruses and may thus represent a broad-spectrum antiviral $[163,180]$. The anti-HCV activity of $\mathrm{CH} 25 \mathrm{H}$ appears to be mediated through $25 \mathrm{HC}$-dependent and independent events including the interaction with NS5A that prevents NS5A dimerization required for viral replication, the inhibition of the formation of the membranous web, and the disruption of the function of the transcription factors sterol regulatory element-binding proteins (SREBPs), thereby perturbing the host lipid metabolism [177,179].

In addition to its role in HCV genome translation as described above, miR-122 is a hepatocyte-specific host factor essential for HCV replication. Indeed, HCV cannot replicate in cells lacking miR-122 or in which miR-122 has been sequestered [123,181-185]. The viral RNA contains two adjacent miR-122 sites in its $5^{\prime}$ UTR and miR-122 binding to the HCV genome promotes viral replication [186,187]. MiR-122 thus represents an interesting target for antiviral therapy (reviewed in [188]) and the miR-122 inhibitor miravirsen has proven its efficacy in reducing viral loads in chronic hepatitis $C$ patients in phase $1 / 2$ clinical trials $[28,29]$. The antiviral activity of miravirsen may be due to two complementary mechanisms: the hybridizing to mature miR-122 that blocks its interaction with HCV RNA, and the binding to the stem-loop structure of pri- and pre-miR-122 that inhibits processing of miR-122 precursors [189].

Besides inhibiting host factors required for viral replication, HCV replication may also be inhibited by modulating host factors that restrict $\mathrm{HCV}$ replication, e.g., the elongation factor $\mathrm{Tu}$ GTP binding domain containing 2 (EFTUD2) and the human cytidine deaminase APOBEC3G (hA3G) [190-192]. Interestingly, hA3G stabilizers exhibit antiviral activity against HCV as hA3G binds to NS3, thereby inhibiting its helicase activity required for viral replication $[190,193]$. Given their original mechanism of action, this class of HTAs may deserve further research to optimize their activity.

Interestingly, compounds inhibiting histone deacetylase 6 (HDAC6) have also been reported to inhibit HCV replication [194,195]. The mechanism of action appears to involve hyperacetylation of $\alpha$-tubulin [194]. Finally, a signal transducer and activator of transcription 3 (STAT3) inhibitor with anti-HCV effect has recently been uncovered in a high-throughput screen [135]. Indeed, STAT3 has been reported to be activated by HCV core and NS5A and to act as a proviral factor for HCV replication [196-198].

\subsection{Assembly/Release Inhibitors to Prevent Generation and Release of New Virions}

A remarkable hallmark of HCV is its association with VLDL/low density lipoprotein (LDL) to form an infectious lipoviroparticle (LVP) [199]. Intracellular assembly and egress of LVP depend on numerous factors involved in lipid metabolism (reviewed in $[162,200]$ ) and are closely linked to the VLDL production machinery [201]. Among the main factors involved in this process are lipid droplets (LDs), intracellular organelles that originate from triglyceride (TG) and cholesterol ester (CE) accumulation between the two leaflets of the ER bilayer [202]. This microenvironment 
represents the "platform" for HCV particle assembly. Several host factors involved in TG biosynthesis and LD biogenesis have been demonstrated to contribute to this process and thus represent targets for HTAs (Figure 3). Indeed, HCV morphogenesis is triggered by the recruitment of the viral core protein from the ER to LDs [203], a process mediated by the diacylglycerol acyltransferase-1 (DGAT-1) (Figure 3). Interestingly, a DGAT-1 chemical inhibitor, currently in clinical trials for metabolic diseases (reviewed in [204]), might serve as an antiviral against HCV infection [205]. Notably, since in hepatocytes DGAT-2 has redundant functions in LD morphogenesis, this DGAT-1-specific inhibitor did not impair LD homeostasis in vitro [205]. The safety of DGAT-1 inhibitor LCQ908 has already been evaluated in HCV-infected patients (https://clinicaltrials.gov/; Identifier: NCT01387958), but additional studies are needed to assess its antiviral efficacy in patients.

Core recruitment to LDs also depends on the composition and the fluidity of ER lipid bilayers that is regulated by the cytosolic phospholipase A2, group 4A, (PLA2G4A) and upstream mitogen-activated protein kinases-extracellular signal regulated kinases (MAPK/ERK). PLA2G4A has been shown to contribute to HCV assembly since pyrrolidine-2 (Py-2), a chemical inhibitor of PLA2G4A, induces aberrant HCV particle production [206]. Furthermore, selective inhibitors of the MAPK/ERK pathway can block infectious HCV production [206,207]. However, opposite studies demonstrated that inhibition of the Ras/Raf/MEK/ERK pathway enhances HCV translation/replication, and disturbs IFN signaling [208-210]. The potential of MAPK inhibitors as antivirals thus remains to be further investigated. The cytosolic phospholipase A2, group 4C, (PLA2G4C) is another enzyme involved in LD homeostasis that can be targeted by HTAs to inhibit assembly. Indeed, the "methyl arachidonyl fluorophosphonate" molecule (MAFP) significantly reduced $\mathrm{HCV}$ assembly by sequestering viral proteins to the ER prior to virion assembly [211].

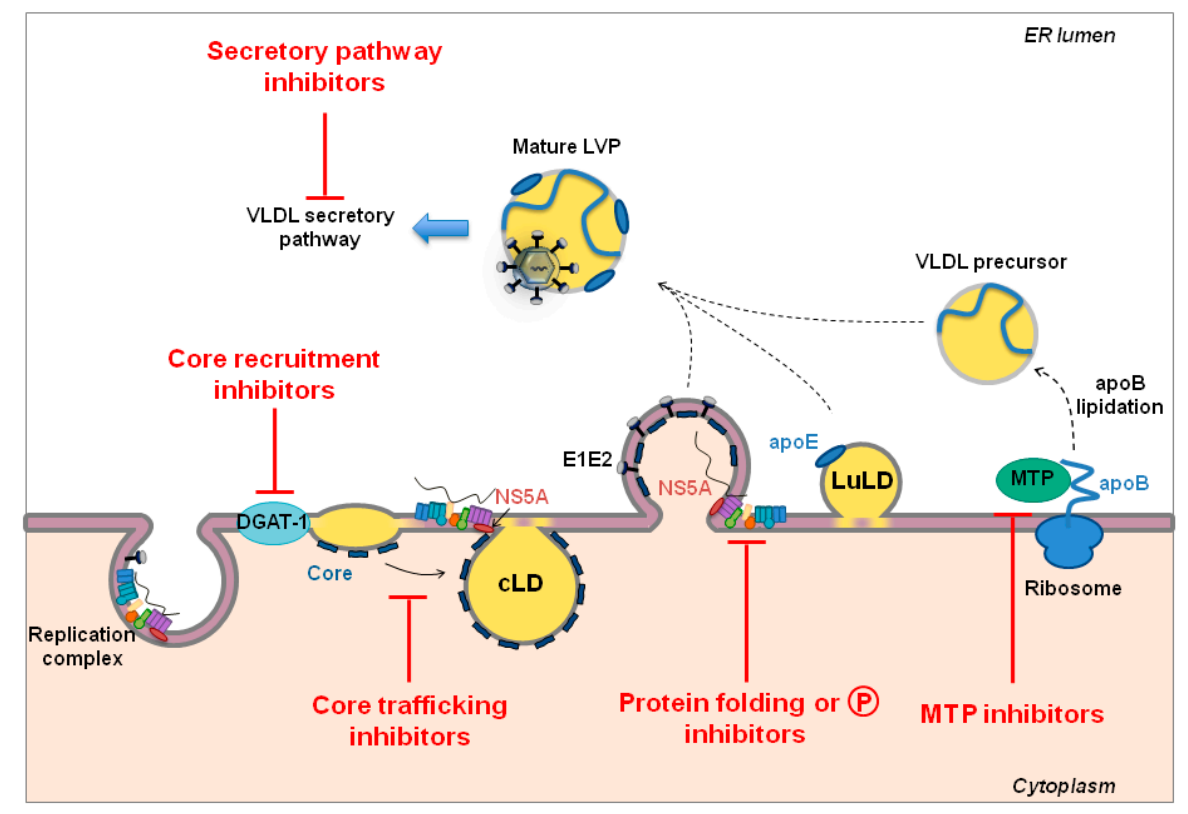

Figure 3. Schematic representation of HCV assembly. Virion assembly is triggered by core recruitment on cytosolic lipid droplets (cLDs) by the diacylglycerol acyltransferase-1 (DGAT-1). In turn, replication complexes are recruited through core-NS5A interactions. Nucleocapsid formation is mediated by viral budding into the ER lumen, at the site of VLDL production. The immature viral particles fuse or attach to a luminal LD (LuLD) through apoE-E1E2 and apoE-NS5A interactions. During VLDL synthesis, apolipoprotein B (apoB) is directly produced in the ER lumen and enriched in lipids by the microsomal triglyceride transfer protein (MTP) to generate VLDL precursors. Viral particles merge with these nascent VLDLs to generate mature lipoviroparticles (LVPs). LVPs enter the VLDL maturation and secretion pathway to be released from hepatocytes. HCV assembly and egress can be impaired by targeting different steps of these processes as highlighted in red. 
Directly targeting core trafficking in hepatocytes also represents an interesting antiviral strategy given the numerous host factors involved in this process (Figure 3). These include AP2M1, the $\mu$ subunit of the clathrin adaptor protein complex 2 (AP-2) that interacts with the core protein through a process involving the adaptor-associated kinase 1 (AAK1) and the cyclin-associated kinase (GAK) [79,96,212]. Approved anticancer kinase inhibitors, such as erlotinib or dasatinib targeting GAK and sunitinib or PKC-412 targeting AAK1, can disrupt core-AP2M1 interaction and, thus, HCV assembly $[79,96,213]$. However, it has to be pointed out that these compounds were initially designed to target other kinases-some of which are involved in HCV entry (see Section 2.1 above) —and thus lack selectivity for GAK and AAKI. The recently reported GAK inhibitor isothiazolo[5,4-b]pyridine that displays limited off-target binding to other kinases efficiently inhibits HCV entry and assembly, and may thus be further developed as a potential antiviral [96].

Other HTAs interfering with host cell lipid metabolism have been reported to display antiviral activity against HCV. Indeed, resveratrol that increases the expression of PPAR $\alpha$, a nuclear transcription factor that activates fatty acid oxidation and is decreased by the core protein [214,215], impairs HCV assembly and secretion by enhancing consumption of fatty acids [216]. Moreover, recent screens identified pterostilbene, a methylated form of resveratrol, toremifene, an estrogen receptor modulator similar to tamoxifen, and quinidine, an antiarrhythmic drug, as potential antivirals against HCV [11,12]. Naringenin was also shown to block production of infectious HCV particles through the activation of PPAR $\alpha$ [36]. Interestingly, HCV can also repress PPAR $\alpha$ activity and lipid accumulation by inducing up-regulation of miR-27b and bezafibrate, a PPAR $\alpha$ agonist, which reverses miR-27b-induced lipid accumulation [217]. This indicates the potential of additional strategies to design novel HTAs against HCV.

Besides core, NS5A is another major player within the HCV replication cycle that connects replication and assembly. NS5A-core interaction on LDs is a crucial step for viral assembly [203,218-220]. Assembly competence of NS5A is mediated by the Caseine Kinase (CK)-mediated phosphorylation of multiple serine and threonine residues [221,222]. Indeed, the specific CKII inhibitor, 2-dimethylamino-4,5,6,7-tetrabromo-1H-benzimidazole (DMAT), was shown to dramatically disrupt virion biogenesis [221] (Figure 3). However, HCV genotype 1a virus production did not appear to be affected by DMAT [223]. Thus, genotype-specific differences might have to be taken into account for potential future clinical application of such inhibitors. To date, one chemical inhibitor of CKII, CX-4945, has entered clinical trials for its antitumor activity, but the potential antiviral effect against $\mathrm{HCV}$ remains to be determined [224].

HCV particle assembly and egress appear to share several host factors with VLDL assembly and secretion pathways [201,225] (Figure 3). The early step of VLDL synthesis consists of lipidation of the newly synthetized apolipoprotein $B(a p o B)$ across the ER membrane by the microsomal triglyceride transfer protein (MTP). In the second step, the VLDL precursors are enriched in lipids via fusion with resident apoE containing LDs (for a review, see [226]). Accumulating evidence demonstrates the crucial role of apoE in HCV assembly [62,63,227-231], while the role of apoB and MTP still remains unclear and controversial $[62,63,201,225,232]$. Nevertheless, a recent study demonstrated the ability of amiodarone, a cationic amphipathic drug that inhibits MTP activity, to down-regulate HCV assembly and release in cell culture [233] (Figure 3). Several other MTP inhibitors are in clinical trials for the treatment of hyperlipidemia (reviewed in [234]). However, whether amiodarone and other MTP inhibitors display an antiviral effect against HCV in vivo remains to be determined.

The VLDL secretory pathway is also hijacked to facilitate HCV egress from infected hepatocytes [201,225] (Figure 3). VLDL secretion is regulated by the hepatocyte nuclear factor $4 \alpha$ $(\mathrm{HNF} 4 \alpha)$, the most abundant transcription factor in the liver. Interestingly, $\mathrm{HNF} 4 \alpha$ also regulates expression of phospholipase A2 GXIIB (PLA2GXIIB), a crucial host factor for HCV production [235]. HNF4 $\alpha$ down-regulation by bezafibrate dramatically reduced HCV secretion [235]. In line with this study, a meta-analysis showed that bezafibrate is associated with a reduction of viral load in chronically HCV-infected patients [168]. Moreover, in association with IFN and ribavirin, bezafibrate 
has been reported to reduce serum HCV RNA titers and to improve liver dysfunction [37]. Cyps have also been reported to contribute to $\mathrm{HCV}$ virion secretion in addition to their role in viral replication [150]. The Cyp inhibitor NIM811 alters lipid trafficking and decreases apoB secretion through the VLDL pathway, thereby blocking HCV production [236]. The combination of NIM811 with PEG-IFN $\alpha$ showed significant antiviral activity compared to IFN alone in chronically infected HCV patients [34]. This synergistic effect may be due to the inhibition of both HCV replication and assembly by NIM811.

To counteract HCV proliferation, several studies reported a novel antiviral strategy that uses the human heat shock cognate protein $70(\mathrm{Hsc70})$ as an antiviral target [237-240]. Hsc70 was identified as a part of the viral particle that modulates virion capsid assembly and LD-dependent virus release [241]. IMB-DM122 [237] and N-substituted benzyl matrinic acid [239] inhibit Hsc70 expression through destabilization of Hsc70 mRNA. Treatment of HCV-infected hepatocytes with these components reduced the incorporation of Hsc70 into viral nucleocapsids, and therefore disrupted HCV production. Moreover, both compounds demonstrated good oral pharmacokinetic profiles and high safety in vivo, making these molecules promising candidates for clinical trials $[237,239]$. Recently, it has been reported that (+)-lycoricidine exhibits anti-HCV activity through its inhibitory effect on the expression of Hsc70 [238]. However, the significant cytotoxicity of this compound precluded further development and new phenanthridines with reduced toxicity have been designed [240]. Their potential as antivirals remains to be determined.

Finally, a promising strategy developed to inhibit virion assembly is to interfere with glucosidases that ensure N-glycosylation and folding of HCV envelope glycoproteins E1 and E2 [242] (Figure 3). It was shown that celgosivir, an $\alpha$-glucosidase I inhibitor, leads to reduced viral production and infectivity in vitro. Moreover, celgosivir administration in combination with PEG-IFN $\alpha$ and ribavirin displayed a clinical benefit in genotype 1 chronically infected patients (reviewed in [35]). Long-term studies are needed to confirm its safety in humans.

\section{HTAs to Prevent HCV Resistance}

Given that they target a highly variable virus, the main limitation of DAAs is viral resistance. Viral resistance may be prevented using different strategies including (i) targeting conserved viral sequences less prone to mutation; (ii) using a combination of drugs exhibiting distinct targets and mechanisms of action; and (iii) increasing host antiviral responses. In contrast to the first DAAs, the emergence of viral resistance with recently approved DAAs, such as sofosbuvir, is less frequent but has nevertheless been described [2,243-245]. Given the generally lower barrier to resistance of DAAs as compared to HTAs, the emergence of treatment-resistant viral variants during DAA therapy remains a challenge. By acting through a complementary mechanism of action and by exhibiting a generally higher barrier to resistance, HTAs can be associated with DAAs to prevent viral resistance. Indeed, given their complementary mechanism of action, HTAs and DAAs can act in a synergistic manner to reduce viral loads [13,21,103] (Figure 4). Interestingly, various HTAs may also be combined to synergistically inhibit HCV infection, as demonstrated for combinations of a HTEI and host-targeting replication inhibitor, i.e., a Cyp inhibitor [21]. Furthermore, HTEIs have been demonstrated to prolong viral suppression by DAAs and to prevent viral dissemination of DAA-resistant strains in vitro [21,246,247]. Indeed, although treatment of HCV-infected cells with DAAs rapidly results in a dramatic reduction of viral load in vitro, viral rebound is usually observed following withdrawal of the drug. However, the addition of an HTEI to the cell culture at the time of DAA withdrawal allows the further decrease of the viral load, indicating that HTEIs limit viral rebound from DAA therapy [21,246]. Furthermore, as many HTEIs inhibit cell-to-cell transmission that has been shown to represent the major route of transmission of wild type and DAA-resistant viruses, HTEIs have been demonstrated to limit dissemination of DAA-resistant strains and consequently prevent antiviral resistance [247]. In line with these in vitro data, the Cyp inhibitor alisporivir, currently in phase $2 / 3$ clinical trials, has been shown to efficiently reduce 
viral loads in chronic hepatitis $C$ patients in combination with ribavirin [32] and future clinical trials evaluating its antiviral effect in combination with DAAs will provide further insights into the potential of this HTA.

Thus far, no viral resistance to HTAs was observed in preclinical or clinical studies $[24,28,248]$. However, some resistant viral variants could be selected by viral passaging in vitro $[75,103]$. This has been first evidenced and most extensively studied with Cyp inhibitors [249-252]. Of note, it was difficult to generate variants exhibiting Cyp inhibitor resistance and the time required to select resistance against these HTAs was significantly longer as compared to DAAs; furthermore, the resistance level was lower $[249,250]$. These data suggested that these viral variants were less dependent on CypA-dependent isomerization of NS5A for their replication [250]. Moreover, while prolonged administration of miravirsen (a miR-122 inhibitor) did not result in the emergence of viral variants exhibiting mutations within the miR-122 binding regions in preclinical and clinical trials $[28,248]$, viral variants exhibiting a single nucleotide change in the $5^{\prime}$ UTR between the miR-122 binding sites and requiring less miR-122 for their replication could be identified in vitro [253]. Whether the emergence of such variants could be avoided by combining miravirsen with other HTAs and/or DAAs with anti-HCV activity remains to be determined. Collectively, these studies indicate that $\mathrm{HCV}$ may become less dependent on defined host factors under selection pressure in vitro. While most mutants were still dependent on Cyp and/or miR-122, specific mutations in NS5A eliminated the dependence of HCV RNA replication on the expression of host CypA [152]. Notably, a recent study reported that $\mathrm{HCV}$ is able to change its host factor dependency under selection pressure. Indeed, in CLDN1 knock-out cells, a CLDN1-dependent strain was able to evolve to use CLDN6 or CLDN9 as a receptor [75]. Whether this may occur in vivo where CLDN1 is expressed at much higher levels than CLDN6 and CLDN9 remains to be determined (reviewed in [254]).

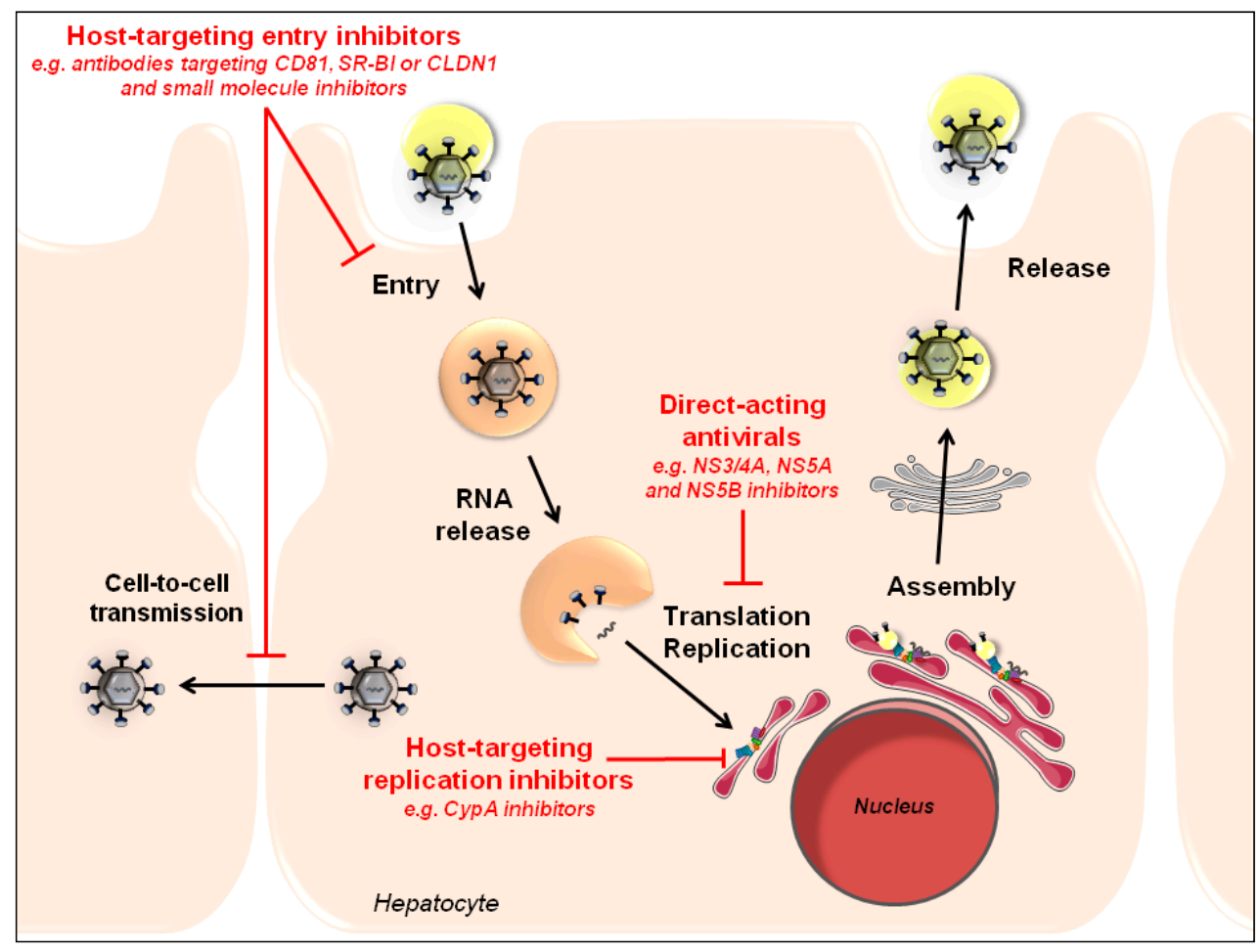

Figure 4. Synergy between HTAs and DAAs to inhibit HCV infection at different steps of the viral life cycle. Given their complementary mechanism of action, HTAs and DAAs can act in a synergistic manner to reduce viral loads and to prevent viral resistance. Different classes of HTAs and DAAs that have been evaluated in combination are highlighted in red. 


\section{Conclusions and Perspectives}

During the last decade, the development of new DAAs considerably improved anti-HCV therapy, displaying high cure rates in treated patients. However, treatment failure and resistance in a subset of patients remain a challenge. Alternative approaches targeting host factors involved in $\mathrm{HCV}$ pathogenesis offer new treatment opportunities. Due to low genetic variability of host factors, HTAs exhibit a high genetic barrier to resistance and display a pan-genotypic antiviral activity.

Several HTAs are currently in development in preclinical or clinical trials (Table 1). Proof-of-concept studies on alisporivir and miravirsen have already shown very high cure rates in phase 2 and 3 clinical trials when used in monotherapy. Preclinical studies have also demonstrated the potential synergistic activity of HTA/DAA combinations to cure HCV infection (Figure 4). Synergy between DAAs and HTAs offers a prospective option for combination therapies for treatment failure to licensed therapies. Furthermore, entry inhibitors, such as anti-receptor antibodies, could offer prevention for HCV graft infection during LT. Indeed, it has been shown that such inhibitors impair cell infection of highly variable quasispecies isolated from individual patients as well as escape variants resistant to host neutralizing antibodies [25,77,78,81-96]. However, their clinical efficacy remains to be demonstrated. To conclude, HTAs may widen the therapeutic arsenal against chronic $\mathrm{HCV}$ infection and simplify HCV therapy.

Acknowledgments: The author's work is supported by Inserm (Institut national de la sante et de la recherche médicale), University of Strasbourg, the European Union (INTERREG-IV-Rhin Supérieur-FEDER-HepatoRegio-Net 2012, FP7 HepaMab and Infect-Era hepBccc), ANRS (Agence Nationale de Recherche sur le Sida et les hépatites virales, 2012/239, 2013/108), Fondation ARC pour la recherche sur le cancer,, Paris, Institut Hospitalo-Universitaire, Strasbourg (TheraHCC IHUARC IHU201301187) and the Initiative of Excellence (IdEx) Program from the University of Strasbourg This work has been published under the framework of the Laboratory of excellence (LABEX) ANR-10-LABX-0028_HEPSYS and benefits from a funding from the state managed by the French National Research Agency as part of the Investments for the future program. E.C. is supported by a fellowship of the French Ministry for Research and Higher Education (MESR).

Author Contributions: M.B.Z and E.C. did the literature search and wrote the manuscript. M.B.Z., T.F.B. and C.S. edited the manuscript. M.B.Z. and E.C. designed illustrations.

Conflicts of Interest: The authors declare no conflict of interest. Inserm, the University of Strasbourg and Aldevron/Genovac have filed patent applications on monoclonal antibodies targeting host factors and inhibiting HCV infection and kinases as antiviral targets.

\section{References}

1. Lindenbach, B.D.; Thiel, H.J.; Rice, C.M. Flaviviridae: The viruses and their replication. In Fields Virology; Knipe, D.M., Howley, P.M., Eds.; Lippincott-Raven: Philadelphia, PA, USA, 2007; pp. 1101-1152.

2. Chung, R.T.; Baumert, T.F. Curing chronic hepatitis C-The arc of a medical triumph. N. Engl. J. Med. 2014, 370, 1576-1578. [CrossRef] [PubMed]

3. Steinmann, E.; Pietschmann, T. Cell culture systems for hepatitis C virus. Curr. Top. Microbiol. Immunol. 2013, 369, 17-48. [PubMed]

4. Billerbeck, E.; de Jong, Y.; Dorner, M.; de la Fuente, C.; Ploss, A. Animal models for hepatitis C. Curr. Top. Microbiol. Immunol. 2013, 369, 49-86. [PubMed]

5. Mailly, L.; Robinet, E.; Meuleman, P.; Baumert, T.F.; Zeisel, M.B. Hepatitis C virus infection and related liver disease: The quest for the best animal model. Front. Microbiol. 2013, 4, 213. [CrossRef] [PubMed]

6. Zeisel, M.B.; Felmlee, D.J.; Baumert, T.F. Hepatitis C virus entry. Curr. Top. Microbiol. Immunol. 2013, 369, 87-112. [PubMed]

7. Niepmann, M. Hepatitis C virus RNA translation. Curr. Top. Microbiol. Immunol. 2013, 369, $143-166$. [PubMed]

8. Lohmann, V. Hepatitis C virus RNA replication. Curr. Top. Microbiol. Immunol. 2013, 369, 167-198. [PubMed]

9. Lindenbach, B.D. Virion assembly and release. Curr. Top. Microbiol. Immunol. 2013, 369, 199-218. [PubMed]

10. Baugh, J.M.; Garcia-Rivera, J.A.; Gallay, P.A. Host-targeting agents in the treatment of hepatitis C: A beginning and an end? Antivir. Res. 2013, 100, 555-561. [CrossRef] [PubMed] 
11. Gastaminza, P.; Whitten-Bauer, C.; Chisari, F.V. Unbiased probing of the entire hepatitis C virus life cycle identifies clinical compounds that target multiple aspects of the infection. Proc. Natl. Acad. Sci. USA 2010, 107, 291-296. [CrossRef] [PubMed]

12. Chockalingam, K.; Simeon, R.L.; Rice, C.M.; Chen, Z. A cell protection screen reveals potent inhibitors of multiple stages of the hepatitis C virus life cycle. Proc. Natl. Acad. Sci. USA 2010, 107, 3764-3769. [CrossRef] [PubMed]

13. He, S.; Lin, B.; Chu, V.; Hu, Z.; Hu, X.; Xiao, J.; Wang, A.Q.; Schweitzer, C.J.; Li, Q.; Imamura, M.; et al. Repurposing of the antihistamine chlorcyclizine and related compounds for treatment of hepatitis $C$ virus infection. Sci. Transl. Med. 2015, 7. [CrossRef] [PubMed]

14. Libri, N.A.; Barker, S.J.; Rosenberg, W.M.; Semper, A.E. A class C CpG toll-like receptor 9 agonist successfully induces robust interferon-alpha production by plasmacytoid dendritic cells from patients chronically infected with hepatitis C. J. Viral Hepat. 2009, 16, 315-324. [CrossRef] [PubMed]

15. Bergmann, J.F.; de Bruijne, J.; Hotho, D.M.; de Knegt, R.J.; Boonstra, A.; Weegink, C.J.; van Vliet, A.A.; van de Wetering, J.; Fletcher, S.P.; Bauman, L.A.; et al. Randomised clinical trial: Anti-viral activity of ANA773, an oral inducer of endogenous interferons acting via TLR7, in chronic HCV. Aliment. Pharmacol. Ther. 2011, 34, 443-453. [CrossRef] [PubMed]

16. Boonstra, A.; Liu, B.S.; Groothuismink, Z.M.; Bergmann, J.F.; de Bruijne, J.; Hotho, D.M.; Hansen, B.E.; van Vliet, A.A.; van de Wetering de Rooij, J.; Fletcher, S.P.; et al. Potent immune activation in chronic hepatitis $C$ patients upon administration of an oral inducer of endogenous interferons that acts via Toll-like receptor 7. Antivir. Ther. 2012, 17, 657-667. [CrossRef] [PubMed]

17. McHutchison, J.G.; Bacon, B.R.; Gordon, S.C.; Lawitz, E.; Shiffman, M.; Afdhal, N.H.; Jacobson, I.M.; Muir, A.; Al-Adhami, M.; Morris, M.L.; et al. Phase 1B, randomized, double-blind, dose-escalation trial of CPG 10101 in patients with chronic hepatitis C virus. Hepatology 2007, 46, 1341-1349. [CrossRef] [PubMed]

18. Meuleman, P.; Hesselgesser, J.; Paulson, M.; vanwolleghem, T.; Desombere, I.; Reiser, H.; Leroux-Roels, G. Anti-CD81 antibodies can prevent a hepatitis C virus infection in vivo. Hepatology 2008, 48, 1761-1768. [CrossRef] [PubMed]

19. Lacek, K.; Vercauteren, K.; Grzyb, K.; Naddeo, M.; Verhoye, L.; Slowikowski, M.P.; Fafi-Kremer, S.; Patel, A.H.; Baumert, T.F.; Folgori, A.; et al. Novel human SR-BI antibodies prevent infection and dissemination of HCV in vitro and in humanized mice. J. Hepatol. 2012, 57, 17-23. [CrossRef] [PubMed]

20. Vercauteren, K.; van den Eede, N.; Mesalam, A.A.; Belouzard, S.; Catanese, M.T.; Bankwitz, D.; Wong-Staal, F.; Cortese, R.; Dubuisson, J.; Rice, C.M.; et al. Successful anti-scavenger receptor class B type I (SR-BI) monoclonal antibody therapy in humanized mice after challenge with HCV variants with in vitro resistance to SR-BI-targeting agents. Hepatology 2014, 60, 1508-1518. [CrossRef] [PubMed]

21. Xiao, F.; Fofana, I.; Thumann, C.; Mailly, L.; Alles, R.; Robinet, E.; Meyer, N.; Schaeffer, M.; Habersetzer, F.; Doffoel, M.; et al. Synergy of entry inhibitors with direct-acting antivirals uncovers novel combinations for prevention and treatment of hepatitis C. Gut 2015, 64, 483-494. [CrossRef] [PubMed]

22. Masson, D.; Koseki, M.; Ishibashi, M.; Larson, C.J.; Miller, S.G.; King, B.D.; Tall, A.R. Increased HDL cholesterol and apoA-I in humans and mice treated with a novel SR-BI inhibitor. Arterioscler. Thromb. Vasc. Biol. 2009, 29, 2054-2060. [CrossRef] [PubMed]

23. Sulkowski, M.S.; Kang, M.; Matining, R.; Wyles, D.; Johnson, V.A.; Morse, G.D.; Amorosa, V.; Bhattacharya, D.; Coughlin, K.; Wong-Staal, F.; et al. Safety and antiviral activity of the HCV entry inhibitor ITX5061 in treatment-naive HCV-infected adults: A randomized, double-blind, phase 1b study. J. Infect. Dis. 2014, 209, 658-667. [CrossRef] [PubMed]

24. Mailly, L.; Xiao, F.; Lupberger, J.; Wilson, G.K.; Aubert, P.; Duong, F.H.; Calabrese, D.; Leboeuf, C.; Fofana, I.; Thumann, C.; et al. Clearance of persistent hepatitis $C$ virus infection in humanized mice using a claudin-1-targeting monoclonal antibody. Nat. Biotechnol. 2015, 33, 549-554. [CrossRef] [PubMed]

25. Sainz, B., Jr.; Barretto, N.; Martin, D.N.; Hiraga, N.; Imamura, M.; Hussain, S.; Marsh, K.A.; Yu, X.; Chayama, K.; Alrefai, W.A.; et al. Identification of the Niemann-Pick C1-like 1 cholesterol absorption receptor as a new hepatitis $C$ virus entry factor. Nat. Med. 2012, 18, 281-285. [CrossRef] [PubMed]

26. Marino, Z.; Crespo, G.; D’Amato, M.; Brambilla, N.; Giacovelli, G.; Rovati, L.; Costa, J.; Navasa, M.; Forns, X. Intravenous silibinin monotherapy shows significant antiviral activity in HCV-infected patients in the peri-transplantation period. J. Hepatol. 2013, 58, 415-420. [CrossRef] [PubMed] 
27. Fried, M.W.; Navarro, V.J.; Afdhal, N.; Belle, S.H.; Wahed, A.S.; Hawke, R.L.; Doo, E.; Meyers, C.M.; Reddy, K.R. Effect of silymarin (milk thistle) on liver disease in patients with chronic hepatitis C unsuccessfully treated with interferon therapy: A randomized controlled trial. JAMA 2012, 308, 274-282. [CrossRef] [PubMed]

28. Janssen, H.L.; Kauppinen, S.; Hodges, M.R. HCV infection and miravirsen. N. Engl. J. Med. 2013, 369, 877-878.

29. Van der Ree, M.H.; van der Meer, A.J.; de Bruijne, J.; Maan, R.; van Vliet, A.; Welzel, T.M.; Zeuzem, S.; Lawitz, E.J.; Rodriguez-Torres, M.; Kupcova, V.; et al. Long-term safety and efficacy of microRNA-targeted therapy in chronic hepatitis C patients. Antivir. Res. 2014, 111, 53-59. [CrossRef] [PubMed]

30. Harrison, S.A.; Rossaro, L.; Hu, K.Q.; Patel, K.; Tillmann, H.; Dhaliwal, S.; Torres, D.M.; Koury, K.; Goteti, V.S.; Noviello, S.; et al. Serum cholesterol and statin use predict virological response to peginterferon and ribavirin therapy. Hepatology 2010, 52, 864-874. [CrossRef] [PubMed]

31. Rao, G.A.; Pandya, P.K. Statin therapy improves sustained virologic response among diabetic patients with chronic hepatitis C. Gastroenterology 2011, 140, 144-152. [CrossRef] [PubMed]

32. Pawlotsky, J.M.; Flisiak, R.; Sarin, S.K.; Rasenack, J.; Piratvisuth, T.; Chuang, W.L.; Peng, C.Y.; Foster, G.R.; Shah, S.; Wedemeyer, H.; et al. Alisporivir plus ribavirin, interferon-free or in combination with peg-interferon, for HCV genotype 2 or 3 infection. Hepatology 2015, 62, 1013-1023. [CrossRef] [PubMed]

33. Hopkins, S.; Dimassimo, B.; Rusnak, P.; Heuman, D.; Lalezari, J.; Sluder, A.; Scorneaux, B.; Mosier, S.; Kowalczyk, P.; Ribeill, Y.; et al. The cyclophilin inhibitor SCY-635 suppresses viral replication and induces endogenous interferons in patients with chronic HCV genotype 1 infection. J. Hepatol. 2012, 57, 47-54. [CrossRef] [PubMed]

34. Lawitz, E.; Godofsky, E.; Rouzier, R.; Marbury, T.; Nguyen, T.; Ke, J.; Huang, M.; Praestgaard, J.; Serra, D.; Evans, T.G. Safety, pharmacokinetics, and antiviral activity of the cyclophilin inhibitor NIM811 alone or in combination with pegylated interferon in HCV-infected patients receiving 14 days of therapy. Antivir. Res. 2011, 89, 238-245. [CrossRef] [PubMed]

35. Durantel, D. Celgosivir, an alpha-glucosidase I inhibitor for the potential treatment of HCV infection. Curr. Opin. Investig. Drugs 2009, 10, 860-870. [PubMed]

36. Goldwasser, J.; Cohen, P.Y.; Lin, W.; Kitsberg, D.; Balaguer, P.; Polyak, S.J.; Chung, R.T.; Yarmush, M.L.; Nahmias, Y. Naringenin inhibits the assembly and long-term production of infectious hepatitis $C$ virus particles through a PPAR-mediated mechanism. J. Hepatol. 2011, 55, 963-971. [CrossRef] [PubMed]

37. Fujita, N.; Kaito, M.; Kai, M.; Sugimoto, R.; Tanaka, H.; Horiike, S.; Konishi, M.; Iwasa, M.; Watanabe, S.; Adachi, Y. Effects of bezafibrate in patients with chronic hepatitis $C$ virus infection: Combination with interferon and ribavirin. J. Viral Hepat. 2006, 13, 441-448. [CrossRef] [PubMed]

38. Ciancio, A.; Andreone, P.; Kaiser, S.; Mangia, A.; Milella, M.; Sola, R.; Pol, S.; Tsianos, E.; de Rosa, A.; Camerini, R.; et al. Thymosin alpha-1 with peginterferon alfa-2a/ribavirin for chronic hepatitis $\mathrm{C}$ not responsive to IFN/ribavirin: An adjuvant role? J. Viral Hepat. 2012, 19 (Suppl. S1), 52-59. [CrossRef] [PubMed]

39. Rossignol, J.F.; Elfert, A.; El-Gohary, Y.; Keeffe, E.B. Improved virologic response in chronic hepatitis C genotype 4 treated with nitazoxanide, peginterferon, and ribavirin. Gastroenterology 2009, 136, 856-862. [CrossRef] [PubMed]

40. Shehab, H.M.; Elbaz, T.M.; Deraz, D.M. Nitazoxanide plus pegylated interferon and ribavirin in the treatment of genotype 4 chronic hepatitis C, a randomized controlled trial. Liver Int. 2014, 34, 259-265. [CrossRef] [PubMed]

41. Barth, H.; Schäfer, C.; Adah, M.I.; Zhang, F.; Linhardt, R.J.; Toyoda, H.; Kinoshita-Toyoda, A.; Toida, T.; van Kuppevelt, T.H.; Depla, E.; et al. Cellular binding of hepatitis C virus envelope glycoprotein E2 requires cell surface heparan sulfate. J. Biol. Chem. 2003, 278, 41003-41012. [CrossRef] [PubMed]

42. Barth, H.; Schnober, E.K.; Zhang, F.; Linhardt, R.J.; Depla, E.; Boson, B.; Cosset, F.L.; Patel, A.H.; Blum, H.E.; Baumert, T.F. Viral and cellular determinants of the hepatitis $C$ virus envelope-heparan sulfate interaction. J. Virol. 2006, 80, 10579-10590. [CrossRef] [PubMed]

43. Haberstroh, A.; Schnober, E.K.; Zeisel, M.B.; Carolla, P.; Barth, H.; Blum, H.E.; Cosset, F.L.; Koutsoudakis, G.; Bartenschlager, R.; Union, A.; et al. Neutralizing host responses in hepatitis C virus infection target viral entry at postbinding steps and membrane fusion. Gastroenterology 2008, 135, 1719-1728.e1. [CrossRef] [PubMed] 
44. Jiang, J.; Cun, W.; Wu, X.; Shi, Q.; Tang, H.; Luo, G. Hepatitis C Virus Attachment Mediated by Apolipoprotein E Binding to Cell Surface Heparan Sulfate. J. Virol. 2012, 86, 7256-7267. [CrossRef] [PubMed]

45. Jiang, J.; Wu, X.; Tang, H.; Luo, G. Apolipoprotein E mediates attachment of clinical hepatitis C virus to hepatocytes by binding to cell surface heparan sulfate proteoglycan receptors. PLoS ONE 2013, 8, e67982. [CrossRef] [PubMed]

46. Xu, Y.; Martinez, P.; Seron, K.; Luo, G.; Allain, F.; Dubuisson, J.; Belouzard, S. Characterization of hepatitis C virus interaction with heparan sulfate proteoglycans. J. Virol. 2015, 89, 3846-3858. [CrossRef] [PubMed]

47. Shi, Q.; Jiang, J.; Luo, G. Syndecan-1 Serves as the Major Receptor for Attachment of Hepatitis C Virus to the surface of hepatocytes. J. Virol. 2013, 87, 6866-6875. [CrossRef] [PubMed]

48. Lefevre, M.; Felmlee, D.J.; Parnot, M.; Baumert, T.F.; Schuster, C. Syndecan 4 is involved in mediating HCV entry through interaction with lipoviral particle-associated apolipoprotein E. PLoS ONE 2014, 9, e95550. [CrossRef] [PubMed]

49. Monazahian, M.; Bohme, I.; Bonk, S.; Koch, A.; Scholz, C.; Grethe, S.; Thomssen, R. Low density lipoprotein receptor as a candidate receptor for hepatitis C virus. J. Med. Virol. 1999, 57, 223-229. [CrossRef]

50. Agnello, V.; Abel, G.; Elfahal, M.; Knight, G.B.; Zhang, Q.X. Hepatitis C virus and other flaviviridae viruses enter cells via low density lipoprotein receptor. Proc. Natl. Acad. Sci. USA 1999, 96, 12766-12771. [CrossRef] [PubMed]

51. Wunschmann, S.; Medh, J.D.; Klinzmann, D.; Schmidt, W.N.; Stapleton, J.T. Characterization of hepatitis C virus (HCV) and HCV E2 interactions with CD81 and the low-density lipoprotein receptor. J. Virol. 2000, 74, 10055-10062. [CrossRef] [PubMed]

52. Germi, R.; Crance, J.M.; Garin, D.; Guimet, J.; Lortat-Jacob, H.; Ruigrok, R.W.; Zarski, J.P.; Drouet, E. Cellular glycosaminoglycans and low density lipoprotein receptor are involved in hepatitis $\mathrm{C}$ virus adsorption. J. Med. Virol. 2002, 68, 206-215. [CrossRef] [PubMed]

53. Prentoe, J.; Serre, S.B.; Ramirez, S.; Nicosia, A.; Gottwein, J.M.; Bukh, J. Hypervariable region 1 deletion and required adaptive envelope mutations confer decreased dependency on scavenger receptor class B type I and low-density lipoprotein receptor for hepatitis C virus. J. Virol. 2014, 88, 1725-1739. [CrossRef] [PubMed]

54. Scarselli, E.; Ansuini, H.; Cerino, R.; Roccasecca, R.M.; Acali, S.; Filocamo, G.; Traboni, C.; Nicosia, A.; Cortese, R.; Vitelli, A. The human scavenger receptor class B type I is a novel candidate receptor for the hepatitis C virus. EMBO J. 2002, 21, 5017-5025. [CrossRef] [PubMed]

55. Bartosch, B.; Vitelli, A.; Granier, C.; Goujon, C.; Dubuisson, J.; Pascale, S.; Scarselli, E.; Cortese, R.; Nicosia, A.; Cosset, F.L. Cell entry of hepatitis $C$ virus requires a set of co-receptors that include the CD81 tetraspanin and the SR-B1 scavenger receptor. J. Biol. Chem. 2003, 278, 41624-41630. [CrossRef] [PubMed]

56. Barth, H.; Cerino, R.; Arcuri, M.; Hoffmann, M.; Schurmann, P.; Adah, M.I.; Gissler, B.; Zhao, X.; Ghisetti, V.; Lavezzo, B.; et al. Scavenger receptor class B type I and hepatitis C virus infection of primary tupaia hepatocytes. J. Virol. 2005, 79, 5774-5785. [CrossRef] [PubMed]

57. Maillard, P.; Huby, T.; Andreo, U.; Moreau, M.; Chapman, J.; Budkowska, A. The interaction of natural hepatitis $\mathrm{C}$ virus with human scavenger receptor SR-BI/Cla1 is mediated by ApoB-containing lipoproteins. Faseb J. 2006, 20, 735-737. [CrossRef] [PubMed]

58. Dreux, M.; Dao Thi, V.L.; Fresquet, J.; Guerin, M.; Julia, Z.; Verney, G.; Durantel, D.; Zoulim, F.; Lavillette, D.; Cosset, F.L.; Bartosch, B. Receptor complementation and mutagenesis reveal SR-BI as an essential HCV entry factor and functionally imply its intra- and extra-cellular domains. PLoS Pathog. 2009, 5, e1000310. [CrossRef] [PubMed]

59. Dao Thi, V.L.; Granier, C.; Zeisel, M.B.; Guerin, M.; Mancip, J.; Granio, O.; Penin, F.; Lavillette, D.; Bartenschlager, R.; Baumert, T.F.; et al. Characterization of Hepatitis C Virus Particle Subpopulations Reveals Multiple Usage of the Scavenger Receptor BI for Entry Steps. J. Biol. Chem. 2012, 287, 31242-31257. [CrossRef] [PubMed]

60. Lindenbach, B.D.; Rice, C.M. The ins and outs of hepatitis C virus entry and assembly. Nat. Rev. Microbiol. 2013, 11, 688-700. [CrossRef] [PubMed]

61. Krepstakies, M.; Lucifora, J.; Nagel, C.H.; Zeisel, M.B.; Holstermann, B.; Hohenberg, H.; Kowalski, I.; Gutsmann, T.; Baumert, T.F.; Brandenburg, K.; et al. A new class of synthetic peptide inhibitors blocks 
attachment and entry of human pathogenic viruses. J. Infect. Dis. 2012, 205, 1654-1664. [CrossRef] [PubMed]

62. Chang, K.S.; Jiang, J.; Cai, Z.; Luo, G. Human apolipoprotein e is required for infectivity and production of hepatitis C virus in cell culture. J. Virol. 2007, 81, 13783-13793. [CrossRef] [PubMed]

63. Jiang, J.; Luo, G. Apolipoprotein E but not B is required for the formation of infectious hepatitis $\mathrm{C}$ virus particles. J. Virol. 2009, 83, 12680-12691. [CrossRef] [PubMed]

64. Albecka, A.; Belouzard, S.; de Beeck, A.O.; Descamps, V.; Goueslain, L.; Bertrand-Michel, J.; Terce, F.; Duverlie, G.; Rouille, Y.; Dubuisson, J. Role of low-density lipoprotein receptor in the hepatitis $C$ virus life cycle. Hepatology 2012, 55, 998-1007. [CrossRef] [PubMed]

65. Matsuhisa, K.; Yamane, S.; Okamoto, T.; Watari, A.; Kondoh, M.; Matsuura, Y.; Yagi, K. Anti-HCV effect of Lentinula edodes mycelia solid culture extracts and low-molecular-weight lignin. Biochem. Biophys. Res. Commun. 2015, 462, 52-57. [CrossRef] [PubMed]

66. Raghuraman, A.; Tiwari, V.; Zhao, Q.; Shukla, D.; Debnath, A.K.; Desai, U.R. Viral inhibition studies on sulfated lignin, a chemically modified biopolymer and a potential mimic of heparan sulfate. Biomacromolecules 2007, 8, 1759-1763. [CrossRef] [PubMed]

67. Andreo, U.; Maillard, P.; Kalinina, O.; Walic, M.; Meurs, E.; Martinot, M.; Marcellin, P.; Budkowska, A. Lipoprotein lipase mediates hepatitis $\mathrm{C}$ virus $(\mathrm{HCV})$ cell entry and inhibits HCV infection. Cell. Microbiol. 2007, 9, 2445-2456. [CrossRef] [PubMed]

68. Owen, D.M.; Huang, H.; Ye, J.; Gale, M., Jr. Apolipoprotein E on hepatitis C virion facilitates infection through interaction with low-density lipoprotein receptor. Virology 2009, 394, 99-108. [CrossRef] [PubMed]

69. Maillard, P.; Walic, M.; Meuleman, P.; Roohvand, F.; Huby, T.; le Goff, W.; Leroux-Roels, G.; Pecheur, E.I.; Budkowska, A. Lipoprotein lipase inhibits hepatitis $\mathrm{C}$ virus (HCV) infection by blocking virus cell entry. PLoS ONE 2011, 6, e26637. [CrossRef] [PubMed]

70. Tao, J.; Kang, K.D.; Hall, S.D.; Laube, A.H.; Liu, J.; Renfrow, M.B.; Novak, J.; Luo, G. The Serum Very-Low-Density Lipoprotein Serves as a Restriction Factor against Hepatitis C Virus Infection. J. Virol. 2015, 89, 6782-6791. [CrossRef] [PubMed]

71. Pileri, P.; Uematsu, Y.; Campagnoli, S.; Galli, G.; Falugi, F.; Petracca, R.; Weiner, A.J.; Houghton, M.; Rosa, D.; Grandi, G.; et al. Binding of hepatitis C virus to CD81. Science 1998, 282, 938-941. [CrossRef] [PubMed]

72. Sourisseau, M.; Michta, M.L.; Zony, C.; Israelow, B.; Hopcraft, S.E.; Narbus, C.M.; Parra Martin, A.; Evans, M.J. Temporal analysis of hepatitis $C$ virus cell entry with occludin directed blocking antibodies. PLoS Pathog. 2013, 9, e1003244. [CrossRef] [PubMed]

73. Douam, F.; Dao Thi, V.L.; Maurin, G.; Fresquet, J.; Mompelat, D.; Zeisel, M.B.; Baumert, T.F.; Cosset, F.L.; Lavillette, D. Critical interaction between E1 and E2 glycoproteins determines binding and fusion properties of hepatitis $C$ virus during cell entry. Hepatology 2014, 59, 776-788. [CrossRef] [PubMed]

74. Ren, Q.; Li, C.; Yuan, P.; Cai, C.; Zhang, L.; Luo, G.G.; Wei, W. A Dual-reporter system for real-time monitoring and high-throughput CRISPR/Cas9 library screening of the hepatitis C virus. Sci. Rep. 2015, 5, 8865. [CrossRef] [PubMed]

75. Hopcraft, S.E.; Evans, M.J. Selection of a hepatitis $C$ virus with altered entry factor requirements reveals a genetic interaction between the E1 glycoprotein and claudins. Hepatology 2015. [CrossRef] [PubMed]

76. Park, J.H.; Park, S.; Yang, J.S.; Kwon, O.S.; Kim, S.; Jang, S.K. Discovery of cellular proteins required for the early steps of HCV infection using integrative genomics. PLoS ONE 2013, 8, e60333. [CrossRef] [PubMed]

77. Lupberger, J.; Zeisel, M.B.; Xiao, F.; Thumann, C.; Fofana, I.; Zona, L.; Davis, C.; Mee, C.J.; Turek, M.; Gorke, S.; et al. EGFR and EphA2 are host factors for hepatitis $C$ virus entry and possible targets for antiviral therapy. Nat. Med. 2011, 17, 589-595. [CrossRef] [PubMed]

78. Martin, D.N.; Uprichard, S.L. Identification of transferrin receptor 1 as a hepatitis C virus entry factor. Proc. Natl. Acad. Sci. USA 2013, 110, 10777-10782. [CrossRef] [PubMed]

79. Neveu, G.; Ziv-Av, A.; Barouch-Bentov, R.; Berkerman, E.; Mulholland, J.; Einav, S. AP-2-associated protein kinase 1 and cyclin G-associated kinase regulate hepatitis $C$ virus entry and are potential drug targets. J. Virol. 2015, 89, 4387-4404. [CrossRef] [PubMed]

80. Zona, L.; Tawar, R.G.; Zeisel, M.B.; Xiao, F.; Schuster, C.; Lupberger, J.; Baumert, T.F. CD81-receptor associations-Impact for hepatitis C virus entry and antiviral therapies. Viruses 2014, 6, 875-892. [CrossRef] [PubMed] 
81. VanCompernolle, S.E.; Wiznycia, A.V.; Rush, J.R.; Dhanasekaran, M.; Baures, P.W.; Todd, S.C. Small molecule inhibition of hepatitis C virus E2 binding to CD81. Virology 2003, 314, 371-380. [CrossRef]

82. Cai, L.; de Beer, M.C.; de Beer, F.C.; van der Westhuyzen, D.R. Serum amyloid A is a ligand for scavenger receptor class B type I and inhibits high density lipoprotein binding and selective lipid uptake. J. Biol. Chem. 2005, 280, 2954-2961. [CrossRef] [PubMed]

83. Koutsoudakis, G.; Kaul, A.; Steinmann, E.; Kallis, S.; Lohmann, V.; Pietschmann, T.; Bartenschlager, R. Characterization of the early steps of hepatitis $C$ virus infection by using luciferase reporter viruses. J. Virol. 2006, 80, 5308-5320. [CrossRef] [PubMed]

84. Lavie, M.; Voisset, C.; Vu-Dac, N.; Zurawski, V.; Duverlie, G.; Wychowski, C.; Dubuisson, J. Serum amyloid A has antiviral activity against hepatitis $C$ virus by inhibiting virus entry in a cell culture system. Hepatology 2006, 44, 1626-1634. [CrossRef] [PubMed]

85. Zeisel, M.B.; Koutsoudakis, G.; Schnober, E.K.; Haberstroh, A.; Blum, H.E.; Cosset, F.L.; Wakita, T.; Jaeck, D.; Doffoel, M.; Royer, C.; et al. Scavenger receptor BI is a key host factor for Hepatitis $C$ virus infection required for an entry step closely linked to CD81. Hepatology 2007, 46, 1722-1731. [CrossRef] [PubMed]

86. Krieger, S.E.; Zeisel, M.B.; Davis, C.; Thumann, C.; Harris, H.J.; Schnober, E.K.; Mee, C.; Soulier, E.; Royer, C.; Lambotin, M.; et al. Inhibition of hepatitis $C$ virus infection by anti-claudin-1 antibodies is mediated by neutralization of E2-CD81-claudin-1 associations. Hepatology 2010, 51, 1144-1157. [CrossRef] [PubMed]

87. Fofana, I.; Krieger, S.E.; Grunert, F.; Glauben, S.; Xiao, F.; Fafi-Kremer, S.; Soulier, E.; Royer, C.; Thumann, C.; Mee, C.J.; et al. Monoclonal anti-claudin 1 antibodies prevent hepatitis $\mathrm{C}$ virus infection of primary human hepatocytes. Gastroenterology 2010, 39, 953-964. [CrossRef] [PubMed]

88. Syder, A.J.; Lee, H.; Zeisel, M.B.; Grove, J.; Soulier, E.; Macdonald, J.; Chow, S.; Chang, J.; Baumert, T.F.; McKeating, J.A.; et al. Small molecule scavenger receptor BI antagonists are potent HCV entry inhibitors. J. Hepatol. 2011, 54, 48-55. [CrossRef] [PubMed]

89. Mittapalli, G.K.; Jackson, A.; Zhao, F.; Lee, H.; Chow, S.; McKelvy, J.; Wong-Staal, F.; Macdonald, J.E. Discovery of highly potent small molecule Hepatitis C Virus entry inhibitors. Bioorg. Med. Chem. Lett. 2011, 21, 6852-6855. [CrossRef] [PubMed]

90. Mittapalli, G.K.; Zhao, F.; Jackson, A.; Gao, H.; Lee, H.; Chow, S.; Kaur, M.P.; Nguyen, N.; Zamboni, R.; McKelvy, J.; et al. Discovery of ITX 4520: A highly potent orally bioavailable hepatitis C virus entry inhibitor. Bioorg. Med. Chem. Lett. 2012, 22, 4955-4961. [CrossRef] [PubMed]

91. Si, Y.; Liu, S.; Liu, X.; Jacobs, J.L.; Cheng, M.; Niu, Y.; Jin, Q.; Wang, T.; Yang, W. A human claudin-1-derived peptide inhibits hepatitis $C$ virus entry. Hepatology 2012, 56, 507-515. [CrossRef] [PubMed]

92. Zahid, M.N.; Turek, M.; Xiao, F.; Thi, V.L.; Guerin, M.; Fofana, I.; Bachellier, P.; Thompson, J.; Delang, L.; Neyts, J.; et al. The postbinding activity of scavenger receptor class B type I mediates initiation of hepatitis $C$ virus infection and viral dissemination. Hepatology 2013, 57, 492-504. [CrossRef] [PubMed]

93. Fofana, I.; Xiao, F.; Thumann, C.; Turek, M.; Zona, L.; Tawar, R.G.; Grunert, F.; Thompson, J.; Zeisel, M.B.; Baumert, T.F. A novel monoclonal anti-CD81 antibody produced by genetic immunization efficiently inhibits Hepatitis C virus cell-cell transmission. PLoS ONE 2013, 8, e64221. [CrossRef] [PubMed]

94. Zona, L.; Lupberger, J.; Sidahmed-Adrar, N.; Thumann, C.; Harris, H.J.; Barnes, A.; Florentin, J.; Tawar, R.G.; Xiao, F.; Turek, M.; et al. HRas signal transduction promotes hepatitis $C$ virus cell entry by triggering assembly of the host tetraspanin receptor complex. Cell Host Microbe 2013, 13, 302-313. [CrossRef] [PubMed]

95. Yamashita, M.; Iida, M.; Tada, M.; Shirasago, Y.; Fukasawa, M.; Nagase, S.; Watari, A.; Ishii-Watabe, A.; Yagi, K.; Kondoh, M. Discovery of anti-claudin-1 antibodies as candidate therapeutics against hepatitis C virus. J. Pharmacol. Exp. Ther. 2015, 353, 112-118. [CrossRef] [PubMed]

96. Kovackova, S.; Chang, L.; Bekerman, E.; Neveu, G.; Barouch-Bentov, R.; Chaikuad, A.; Heroven, C.; Sala, M.; de Jonghe, S.; Knapp, S.; et al. Selective Inhibitors of Cyclin G Associated Kinase (GAK) as Anti-Hepatitis C Agents. J. Med. Chem. 2015, 58, 3393-3410. [CrossRef] [PubMed]

97. Meyer, K.; Kwon, Y.C.; Liu, S.; Hagedorn, C.H.; Ray, R.B.; Ray, R. Interferon-alpha inducible protein 6 impairs EGFR activation by CD81 and inhibits hepatitis C virus infection. Sci. Rep. 2015, 5, 9012. [CrossRef] [PubMed]

98. Blanchard, E.; Belouzard, S.; Goueslain, L.; Wakita, T.; Dubuisson, J.; Wychowski, C.; Rouille, Y. Hepatitis C virus entry depends on clathrin-mediated endocytosis. J. Virol. 2006, 80, 6964-6972. [CrossRef] [PubMed] 
99. Matsumura, T.; Hu, Z.; Kato, T.; Dreux, M.; Zhang, Y.Y.; Imamura, M.; Hiraga, N.; Juteau, J.M.; Cosset, F.L.; Chayama, K.; et al. Amphipathic DNA polymers inhibit hepatitis C virus infection by blocking viral entry. Gastroenterology 2009, 137, 673-681. [CrossRef] [PubMed]

100. Wagoner, J.; Negash, A.; Kane, O.J.; Martinez, L.E.; Nahmias, Y.; Bourne, N.; Owen, D.M.; Grove, J.; Brimacombe, C.; McKeating, J.A.; et al. Multiple effects of silymarin on the hepatitis C virus lifecycle. Hepatology 2010, 51, 1912-1921. [CrossRef] [PubMed]

101. Blaising, J.; Levy, P.L.; Polyak, S.J.; Stanifer, M.; Boulant, S.; Pecheur, E.I. Arbidol inhibits viral entry by interfering with clathrin-dependent trafficking. Antivir. Res. 2013, 100, 215-219. [CrossRef]

102. Blaising, J.; Levy, P.L.; Gondeau, C.; Phelip, C.; Varbanov, M.; Teissier, E.; Ruggiero, F.; Polyak, S.J.; Oberlies, N.H.; Ivanovic, T.; et al. Silibinin inhibits hepatitis C virus entry into hepatocytes by hindering clathrin-dependent trafficking. Cell. Microbiol. 2013, 15, 1866-1882. [CrossRef] [PubMed]

103. Vausselin, T.; Calland, N.; Belouzard, S.; Descamps, V.; Douam, F.; Helle, F.; Francois, C.; Lavillette, D.; Duverlie, G.; Wahid, A.; et al. The antimalarial ferroquine is an inhibitor of hepatitis $\mathrm{C}$ virus. Hepatology 2013, 58, 86-97. [CrossRef] [PubMed]

104. Ahmed-Belkacem, A.; Ahnou, N.; Barbotte, L.; Wychowski, C.; Pallier, C.; Brillet, R.; Pohl, R.T.; Pawlotsky, J.M. Silibinin and related compounds are direct inhibitors of hepatitis $C$ virus RNA-dependent RNA polymerase. Gastroenterology 2010, 138, 1112-1122. [CrossRef] [PubMed]

105. Mizui, T.; Yamashina, S.; Tanida, I.; Takei, Y.; Ueno, T.; Sakamoto, N.; Ikejima, K.; Kitamura, T.; Enomoto, N.; Sakai, T.; et al. Inhibition of hepatitis $\mathrm{C}$ virus replication by chloroquine targeting virus-associated autophagy. J. Gastroenterol. 2010, 45, 195-203. [CrossRef] [PubMed]

106. Timpe, J.M.; Stamataki, Z.; Jennings, A.; Hu, K.; Farquhar, M.J.; Harris, H.J.; Schwarz, A.; Desombere, I.; Roels, G.L.; Balfe, P.; et al. Hepatitis C virus cell-cell transmission in hepatoma cells in the presence of neutralizing antibodies. Hepatology 2008, 47, 17-24. [CrossRef] [PubMed]

107. Brimacombe, C.L.; Grove, J.; Meredith, L.W.; Hu, K.; Syder, A.J.; Flores, M.V.; Timpe, J.M.; Krieger, S.E.; Baumert, T.F.; Tellinghuisen, T.L.; et al. Neutralizing antibody-resistant hepatitis C virus cell-to-cell transmission. J. Virol. 2011, 85, 596-605. [CrossRef] [PubMed]

108. Witteveldt, J.; Evans, M.J.; Bitzegeio, J.; Koutsoudakis, G.; Owsianka, A.M.; Angus, A.G.; Keck, Z.Y.; Foung, S.K.; Pietschmann, T.; Rice, C.M.; et al. CD81 is dispensable for hepatitis C virus cell-to-cell transmission in hepatoma cells. J. Gen. Virol. 2009, 90, 48-58. [CrossRef] [PubMed]

109. Catanese, M.T.; Loureiro, J.; Jones, C.T.; Dorner, M.; von Hahn, T.; Rice, C.M. Different requirements for scavenger receptor class B type I in hepatitis C virus cell-free versus cell-to-cell transmission. J. Virol. 2013, 87, 8282-8293. [CrossRef] [PubMed]

110. Meuleman, P.; Catanese, M.T.; Verhoye, L.; Desombere, I.; Farhoudi, A.; Jones, C.T.; Sheahan, T.; Grzyb, K.; Cortese, R.; Rice, C.M.; et al. A human monoclonal antibody targeting scavenger receptor class B type I precludes hepatitis C virus infection and viral spread in vitro and in vivo. Hepatology 2012, 55, 364-372. [CrossRef] [PubMed]

111. Fukasawa, M.; Nagase, S.; Shirasago, Y.; Iida, M.; Yamashita, M.; Endo, K.; Yagi, K.; Suzuki, T.; Wakita, T.; Hanada, K.; et al. Monoclonal antibodies against extracellular domains of claudin-1 block hepatitis $\mathrm{C}$ virus infection in a mouse model. J. Virol. 2015, 89, 4866-4879. [CrossRef] [PubMed]

112. Neumann, U.P.; Biermer, M.; Eurich, D.; Neuhaus, P.; Berg, T. Successful prevention of hepatitis C virus (HCV) liver graft reinfection by silibinin mono-therapy. J. Hepatol. 2010, 52, 951-952. [CrossRef] [PubMed]

113. Payer, B.A.; Reiberger, T.; Rutter, K.; Beinhardt, S.; Staettermayer, A.F.; Peck-Radosavljevic, M.; Ferenci, P. Successful HCV eradication and inhibition of HIV replication by intravenous silibinin in an HIV-HCV coinfected patient. J. Clin. Virol. 2010, 49, 131-133. [CrossRef] [PubMed]

114. Aghemo, A.; Bhoori, S.; de Nicola, S.; Mazzaferro, V.; Colombo, M. Failure of Intravenous Silibinin Monotherapy to Prevent Hepatitis C Genotype 2A Liver Graft Reinfection. Hepat. Mon. 2012, 12, 411-414. [CrossRef] [PubMed]

115. Barcena, R.; Moreno, A.; Rodriguez-Gandia, M.A.; Albillos, A.; Arocena, C.; Blesa, C.; Garcia-Hoz, F.; Graus, J.; Nuno, J.; Lopez-Hervas, P.; et al. Safety and anti-HCV effect of prolonged intravenous silibinin in HCV genotype 1 subjects in the immediate liver transplant period. J. Hepatol. 2013, 58, 421-426. [CrossRef] [PubMed]

116. Tsukiyama-Kohara, K.; Iizuka, N.; Kohara, M.; Nomoto, A. Internal ribosome entry site within hepatitis C virus RNA. J. Virol. 1992, 66, 1476-1483. [PubMed] 
117. Wang, C.; Sarnow, P.; Siddiqui, A. Translation of human hepatitis C virus RNA in cultured cells is mediated by an internal ribosome-binding mechanism. J. Virol. 1993, 67, 3338-3344. [PubMed]

118. Pestova, T.V.; Shatsky, I.N.; Fletcher, S.P.; Jackson, R.J.; Hellen, C.U. A prokaryotic-like mode of cytoplasmic eukaryotic ribosome binding to the initiation codon during internal translation initiation of hepatitis $\mathrm{C}$ and classical swine fever virus RNAs. Genes Dev. 1998, 12, 67-83. [CrossRef] [PubMed]

119. Kieft, J.S.; Zhou, K.; Jubin, R.; Doudna, J.A. Mechanism of ribosome recruitment by hepatitis C IRES RNA. RNA 2001, 7, 194-206. [CrossRef] [PubMed]

120. Fontanes, V.; Raychaudhuri, S.; Dasgupta, A. A cell-permeable peptide inhibits hepatitis C virus replication by sequestering IRES transacting factors. Virology 2009, 394, 82-90. [CrossRef] [PubMed]

121. Bhat, P.; Gnanasundram, S.V.; Mani, P.; Ray, P.S.; Sarkar, D.P.; Das, S. Targeting ribosome assembly on the HCV RNA using a small RNA molecule. RNA Biol. 2012, 9, 1110-1119. [CrossRef] [PubMed]

122. Tsukimoto, A.; Sugiyama, R.; Abe, M.; Nishitsuji, H.; Shimizu, Y.; Shimotohno, K.; Kawai, G.; Takaku, H. A new role for PGA1 in inhibiting hepatitis $C$ virus-IRES-mediated translation by targeting viral translation factors. Antivir. Res. 2015, 117, 1-9. [CrossRef] [PubMed]

123. Jopling, C.L.; Yi, M.; Lancaster, A.M.; Lemon, S.M.; Sarnow, P. Modulation of hepatitis C virus RNA abundance by a liver-specific MicroRNA. Science 2005, 309, 1577-1581. [CrossRef] [PubMed]

124. Henke, J.I.; Goergen, D.; Zheng, J.; Song, Y.; Schuttler, C.G.; Fehr, C.; Junemann, C.; Niepmann, M. microRNA-122 stimulates translation of hepatitis C virus RNA. EMBO J. 2008, 27, 3300-3310. [CrossRef] [PubMed]

125. Sengupta, J.; Nilsson, J.; Gursky, R.; Spahn, C.M.; Nissen, P.; Frank, J. Identification of the versatile scaffold protein RACK1 on the eukaryotic ribosome by cryo-EM. Nat. Struct. Mol. Biol. 2004, 11, 957-962. [CrossRef] [PubMed]

126. Coyle, S.M.; Gilbert, W.V.; Doudna, J.A. Direct link between RACK1 function and localization at the ribosome in vivo. Mol. Cell. Biol. 2009, 29, 1626-1634. [CrossRef] [PubMed]

127. Majzoub, K.; Hafirassou, M.L.; Meignin, C.; Goto, A.; Marzi, S.; Fedorova, A.; Verdier, Y.; Vinh, J.; Hoffmann, J.A.; Martin, F.; et al. RACK1 controls IRES-mediated translation of viruses. Cell 2014, 159, 1086-1095. [CrossRef] [PubMed]

128. Watashi, K.; Ishii, N.; Hijikata, M.; Inoue, D.; Murata, T.; Miyanari, Y.; Shimotohno, K. Cyclophilin B is a functional regulator of hepatitis C virus RNA polymerase. Mol. Cell 2005, 19, 111-122. [CrossRef] [PubMed]

129. Randall, G.; Panis, M.; Cooper, J.D.; Tellinghuisen, T.L.; Sukhodolets, K.E.; Pfeffer, S.; Landthaler, M.; Landgraf, P.; Kan, S.; Lindenbach, B.D.; et al. Cellular cofactors affecting hepatitis C virus infection and replication. Proc. Natl. Acad. Sci. USA 2007, 104, 12884-12889. [CrossRef] [PubMed]

130. Ng, T.I.; Mo, H.; Pilot-Matias, T.; He, Y.; Koev, G.; Krishnan, P.; Mondal, R.; Pithawalla, R.; He, W.; Dekhtyar, T.; et al. Identification of host genes involved in hepatitis $\mathrm{C}$ virus replication by small interfering RNA technology. Hepatology 2007, 45, 1413-1421. [CrossRef] [PubMed]

131. Supekova, L.; Supek, F.; Lee, J.; Chen, S.; Gray, N.; Pezacki, J.P.; Schlapbach, A.; Schultz, P.G. Identification of human kinases involved in hepatitis $C$ virus replication by small interference RNA library screening. J. Biol. Chem. 2008, 283, 29-36. [CrossRef] [PubMed]

132. Berger, K.L.; Cooper, J.D.; Heaton, N.S.; Yoon, R.; Oakland, T.E.; Jordan, T.X.; Mateu, G.; Grakoui, A.; Randall, G. Roles for endocytic trafficking and phosphatidylinositol 4-kinase III alpha in hepatitis $C$ virus replication. Proc. Natl. Acad. Sci. USA 2009, 106, 7577-7582. [CrossRef] [PubMed]

133. Tai, A.W.; Benita, Y.; Peng, L.F.; Kim, S.S.; Sakamoto, N.; Xavier, R.J.; Chung, R.T. A functional genomic screen identifies cellular cofactors of hepatitis C virus replication. Cell Host Microbe 2009, 5, 298-307. [CrossRef] [PubMed]

134. Vaillancourt, F.H.; Pilote, L.; Cartier, M.; Lippens, J.; Liuzzi, M.; Bethell, R.C.; Cordingley, M.G.; Kukolj, G. Identification of a lipid kinase as a host factor involved in hepatitis C virus RNA replication. Virology 2009, 387, 5-10. [CrossRef] [PubMed]

135. Niu, Y.; Si, Y.; Li, Y.; Chi, X.; Li, X.; Liu, X.; Li, D.; Cheng, M.; Fan, J.; Si, S.; Yang, W. A novel small-molecule inhibitor of hepatitis $C$ virus replication acts by suppressing signal transducer and activator of transcription 3. J. Antimicrob. Chemother. 2015, 70, 2013-2023. [CrossRef] [PubMed]

136. Egger, D.; Wolk, B.; Gosert, R.; Bianchi, L.; Blum, H.E.; Moradpour, D.; Bienz, K. Expression of hepatitis C virus proteins induces distinct membrane alterations including a candidate viral replication complex. J. Virol. 2002, 76, 5974-5984. [CrossRef] [PubMed] 
137. Gouttenoire, J.; Roingeard, P.; Penin, F.; Moradpour, D. Amphipathic alpha-helix AH2 is a major determinant for the oligomerization of hepatitis C virus nonstructural protein 4B. J. Virol. 2010, 84, 12529-12537. [CrossRef] [PubMed]

138. Paul, D.; Romero-Brey, I.; Gouttenoire, J.; Stoitsova, S.; Krijnse-Locker, J.; Moradpour, D.; Bartenschlager, R. NS4B self-interaction through conserved C-terminal elements is required for the establishment of functional hepatitis C virus replication complexes. J. Virol. 2011, 85, 6963-6976. [CrossRef] [PubMed]

139. Romero-Brey, I.; Merz, A.; Chiramel, A.; Lee, J.Y.; Chlanda, P.; Haselman, U.; Santarella-Mellwig, R.; Habermann, A.; Hoppe, S.; Kallis, S.; et al. Three-dimensional architecture and biogenesis of membrane structures associated with hepatitis C virus replication. PLoS Pathog. 2012, 8, e1003056. [CrossRef] [PubMed]

140. Ferraris, P.; Blanchard, E.; Roingeard, P. Ultrastructural and biochemical analyses of hepatitis C virus-associated host cell membranes. J. Gen. Virol. 2010, 91, 2230-2237. [CrossRef] [PubMed]

141. Dreux, M.; Chisari, F.V. Impact of the autophagy machinery on hepatitis C virus infection. Viruses 2011, 3, 1342-1357. [CrossRef] [PubMed]

142. Wang, L.; James Ou, J.H. Hepatitis C virus and autophagy. Biol. Chem. 2015. [CrossRef] [PubMed]

143. Sir, D.; Kuo, C.F.; Tian, Y.; Liu, H.M.; Huang, E.J.; Jung, J.U.; Machida, K.; Ou, J.H. Replication of hepatitis C virus RNA on autophagosomal membranes. J. Biol. Chem. 2012, 287, 18036-18043. [CrossRef] [PubMed]

144. Paul, D.; Madan, V.; Bartenschlager, R. Hepatitis C virus RNA replication and assembly: Living on the fat of the land. Cell Host Microbe 2014, 16, 569-579. [CrossRef] [PubMed]

145. Madan, V.; Paul, D.; Lohmann, V.; Bartenschlager, R. Inhibition of HCV replication by cyclophilin antagonists is linked to replication fitness and occurs by inhibition of membranous web formation. Gastroenterology 2014, 146, 1361-1372.e9. [CrossRef] [PubMed]

146. Chao, T.C.; Su, W.C.; Huang, J.Y.; Chen, Y.C.; Jeng, K.S.; Wang, H.D.; Lai, M.M. Proline-serine-threonine phosphatase-interacting protein 2 (PSTPIP2), a host membrane-deforming protein, is critical for membranous web formation in hepatitis C virus replication. J. Virol. 2012, 86, 1739-1749. [CrossRef] [PubMed]

147. Dorner, M.; Horwitz, J.A.; Donovan, B.M.; Labitt, R.N.; Budell, W.C.; Friling, T.; Vogt, A.; Catanese, M.T.; Satoh, T.; Kawai, T.; et al. Completion of the entire hepatitis $\mathrm{C}$ virus life cycle in genetically humanized mice. Nature 2013, 501, 237-241. [CrossRef] [PubMed]

148. Hanoulle, X.; Badillo, A.; Wieruszeski, J.M.; Verdegem, D.; Landrieu, I.; Bartenschlager, R.; Penin, F.; Lippens, G. Hepatitis C virus NS5A protein is a substrate for the peptidyl-prolyl cis/trans isomerase activity of cyclophilins A and B. J. Biol. Chem. 2009, 284, 13589-13601. [CrossRef] [PubMed]

149. Kaul, A.; Stauffer, S.; Berger, C.; Pertel, T.; Schmitt, J.; Kallis, S.; Zayas, M.; Lohmann, V.; Luban, J.; Bartenschlager, R. Essential role of cyclophilin A for hepatitis $C$ virus replication and virus production and possible link to polyprotein cleavage kinetics. PLoS Pathog. 2009, 5, e1000546. [CrossRef] [PubMed]

150. Gaither, L.A.; Borawski, J.; Anderson, L.J.; Balabanis, K.A.; Devay, P.; Joberty, G.; Rau, C.; Schirle, M.; Bouwmeester, T.; Mickanin, C.; et al. Multiple cyclophilins involved in different cellular pathways mediate HCV replication. Virology 2010, 397, 43-55. [CrossRef] [PubMed]

151. Naoumov, N.V. Cyclophilin inhibition as potential therapy for liver diseases. J. Hepatol. 2014, 61, 1166-1174. [CrossRef] [PubMed]

152. Hopkins, S.; Bobardt, M.; Chatterji, U.; Garcia-Rivera, J.A.; Lim, P.; Gallay, P.A. The Cyclophilin Inhibitor SCY-635 Disrupts HCV NS5A-Cyclophilin A Complexes. Antimicrob. Agents Chemother. 2012, 56, 3888-3897. [CrossRef] [PubMed]

153. Hopkins, S.; Scorneaux, B.; Huang, Z.; Murray, M.G.; Wring, S.; Smitley, C.; Harris, R.; Erdmann, F.; Fischer, G.; Ribeill, Y. SCY-635, a novel nonimmunosuppressive analog of cyclosporine that exhibits potent inhibition of hepatitis C virus RNA replication in vitro. Antimicrob. Agents Chemother. 2010, 54, 660-672. [CrossRef] [PubMed]

154. Flisiak, R.; Jaroszewicz, J.; Flisiak, I.; Lapinski, T. Update on alisporivir in treatment of viral hepatitis C. Expert Opin. Investig. Drugs 2012, 21, 375-382. [CrossRef] [PubMed]

155. Reiss, S.; Rebhan, I.; Backes, P.; Romero-Brey, I.; Erfle, H.; Matula, P.; Kaderali, L.; Poenisch, M.; Blankenburg, H.; Hiet, M.S.; et al. Recruitment and activation of a lipid kinase by hepatitis C virus NS5A is essential for integrity of the membranous replication compartment. Cell Host Microbe 2011, 9, $32-45$. [CrossRef] [PubMed] 
156. Reiss, S.; Harak, C.; Romero-Brey, I.; Radujkovic, D.; Klein, R.; Ruggieri, A.; Rebhan, I.; Bartenschlager, R.; Lohmann, V. The lipid kinase phosphatidylinositol-4 kinase III alpha regulates the phosphorylation status of hepatitis C virus NS5A. PLoS Pathog. 2013, 9, e1003359. [CrossRef] [PubMed]

157. Trotard, M.; Lepere-Douard, C.; Regeard, M.; Piquet-Pellorce, C.; Lavillette, D.; Cosset, F.L.; Gripon, P.; le Seyec, J. Kinases required in hepatitis $C$ virus entry and replication highlighted by small interference RNA screening. Faseb J. 2009, 23, 3780-3789. [CrossRef] [PubMed]

158. Borawski, J.; Troke, P.; Puyang, X.; Gibaja, V.; Zhao, S.; Mickanin, C.; Leighton-Davies, J.; Wilson, C.J.; Myer, V.; Cornellataracido, I.; et al. Class III phosphatidylinositol 4-kinase alpha and beta are novel host factor regulators of hepatitis C virus replication. J. Virol. 2009, 83, 10058-10074. [CrossRef] [PubMed]

159. Lamarche, M.J.; Borawski, J.; Bose, A.; Capacci-Daniel, C.; Colvin, R.; Dennehy, M.; Ding, J.; Dobler, M.; Drumm, J.; Gaither, L.A.; et al. Anti-hepatitis C virus activity and toxicity of type III phosphatidylinositol-4-kinase beta inhibitors. Antimicrob. Agents Chemother. 2012, 56, 5149-5156. [CrossRef] [PubMed]

160. Spickler, C.; Lippens, J.; Laberge, M.K.; Desmeules, S.; Bellavance, E.; Garneau, M.; Guo, T.; Hucke, O.; Leyssen, P.; Neyts, J.; et al. Phosphatidylinositol 4-kinase III beta is essential for replication of human rhinovirus and its inhibition causes a lethal phenotype in vivo. Antimicrob. Agents Chemother. 2013, 57, 3358-3368. [CrossRef] [PubMed]

161. Keaney, E.P.; Connolly, M.; Dobler, M.; Karki, R.; Honda, A.; Sokup, S.; Karur, S.; Britt, S.; Patnaik, A.; Raman, P.; et al. 2-Alkyloxazoles as potent and selective PI4KIIIbeta inhibitors demonstrating inhibition of HCV replication. Bioorg. Med. Chem. Lett. 2014, 24, 3714-3718. [CrossRef] [PubMed]

162. Felmlee, D.J.; Hafirassou, M.L.; Lefevre, M.; Baumert, T.F.; Schuster, C. Hepatitis C virus, cholesterol and lipoproteins-Impact for the viral life cycle and pathogenesis of liver disease. Viruses 2013, 5, 1292-1324. [CrossRef] [PubMed]

163. Su, A.I.; Pezacki, J.P.; Wodicka, L.; Brideau, A.D.; Supekova, L.; Thimme, R.; Wieland, S.; Bukh, J.; Purcell, R.H.; Schultz, P.G.; et al. Genomic analysis of the host response to hepatitis C virus infection. Proc. Natl. Acad. Sci. USA 2002, 99, 15669-15674. [CrossRef] [PubMed]

164. Ye, J.; Wang, C.; Sumpter, R., Jr.; Brown, M.S.; Goldstein, J.L.; Gale, M., Jr. Disruption of hepatitis C virus RNA replication through inhibition of host protein geranylgeranylation. Proc Proc. Natl. Acad. Sci. USA 2003, 100, 15865-15870. [CrossRef] [PubMed]

165. Kapadia, S.B.; Chisari, F.V. Hepatitis C virus RNA replication is regulated by host geranylgeranylation and fatty acids. Proc. Natl. Acad. Sci. USA 2005, 102, 2561-2566. [CrossRef] [PubMed]

166. Ikeda, M.; Abe, K.; Yamada, M.; Dansako, H.; Naka, K.; Kato, N. Different anti-HCV profiles of statins and their potential for combination therapy with interferon. Hepatology 2006, 44, 117-125. [CrossRef] [PubMed]

167. Sezaki, H.; Suzuki, F.; Akuta, N.; Yatsuji, H.; Hosaka, T.; Kobayashi, M.; Suzuki, Y.; Arase, Y.; Ikeda, K.; Miyakawa, Y.; et al. An open pilot study exploring the efficacy of fluvastatin, pegylated interferon and ribavirin in patients with hepatitis $C$ virus genotype $1 \mathrm{~b}$ in high viral loads. Intervirology 2009, 52, 43-48. [CrossRef] [PubMed]

168. Grammatikos, G.; Farnik, H.; Bon, D.; Bohlig, A.; Bader, T.; Berg, T.; Zeuzem, S.; Herrmann, E. The impact of antihyperlipidemic drugs on the viral load of patients with chronic hepatitis $C$ infection: A meta-analysis. J. Viral Hepat. 2014, 21, 533-541. [CrossRef] [PubMed]

169. Ali, N.; Allam, H.; Bader, T.; May, R.; Basalingappa, K.M.; Berry, W.L.; Chandrakesan, P.; Qu, D.; Weygant, N.; Bronze, M.S.; et al. Fluvastatin interferes with hepatitis $\mathrm{C}$ virus replication via microtubule bundling and a doublecortin-like kinase-mediated mechanism. PLoS ONE 2013, 8, e80304. [CrossRef] [PubMed]

170. Shan, Y.; Zheng, J.; Lambrecht, R.W.; Bonkovsky, H.L. Reciprocal effects of micro-RNA-122 on expression of heme oxygenase-1 and hepatitis C virus genes in human hepatocytes. Gastroenterology 2007, 133, 1166-1174. [CrossRef] [PubMed]

171. Lehmann, E.; El-Tantawy, W.H.; Ocker, M.; Bartenschlager, R.; Lohmann, V.; Hashemolhosseini, S.; Tiegs, G.; Sass, G. The heme oxygenase 1 product biliverdin interferes with hepatitis $C$ virus replication by increasing antiviral interferon response. Hepatology 2010, 51, 398-404. [CrossRef] [PubMed]

172. Zhu, Z.; Wilson, A.T.; Luxon, B.A.; Brown, K.E.; Mathahs, M.M.; Bandyopadhyay, S.; McCaffrey, A.P.; Schmidt, W.N. Biliverdin inhibits hepatitis $C$ virus nonstructural 3/4A protease activity: Mechanism for the antiviral effects of heme oxygenase? Hepatology 2010, 52, 1897-1905. [CrossRef] [PubMed] 
173. Wuestenberg, A.; Kah, J.; Singethan, K.; Sirma, H.; Keller, A.D.; Rosal, S.R.; Schrader, J.; Loscher, C.; Volz, T.; Bartenschlager, R.; et al. Matrix conditions and KLF2-dependent induction of heme oxygenase-1 modulate inhibition of HCV replication by fluvastatin. PLOS ONE 2014, 9, e96533. [CrossRef] [PubMed]

174. Blanchet, M.; Seidah, N.G.; Labonte, P. SKI-1/S1P inhibition: A promising surrogate to statins to block Hepatitis C virus replication. Antivir. Res. 2012, 95, 159-166. [CrossRef] [PubMed]

175. Olmstead, A.D.; Knecht, W.; Lazarov, I.; Dixit, S.B.; Jean, F. Human subtilase SKI-1/S1P is a master regulator of the HCV Lifecycle and a potential host cell target for developing indirect-acting antiviral agents. PLoS Pathog. 2012, 8, e1002468. [CrossRef] [PubMed]

176. Watashi, K.; Inoue, D.; Hijikata, M.; Goto, K.; Aly, H.H.; Shimotohno, K. Anti-hepatitis C virus activity of tamoxifen reveals the functional association of estrogen receptor with viral RNA polymerase NS5B. J. Biol. Chem. 2007, 282, 32765-32772. [CrossRef] [PubMed]

177. Chen, Y.; Wang, S.; Yi, Z.; Tian, H.; Aliyari, R.; Li, Y.; Chen, G.; Liu, P.; Zhong, J.; Chen, $\mathrm{X}$; et al. Interferon-inducible cholesterol-25-hydroxylase inhibits hepatitis $\mathrm{C}$ virus replication via distinct mechanisms. Sci. Rep. 2014, 4, 7242. [CrossRef] [PubMed]

178. Kusuma, A.; Romero-Brey, I.; Berger, C.; Colpitts, C.C.; Boldanova, T.; Engelmann, M.; Todt, D.; Perin, P.M.; Behrendt, P.; Vondran, F.W.; et al. Interferon-inducible cholesterol-25-hydroxylase restricts hepatitis $C$ virus replication via blockage of membranous web formation. Hepatology 2015, 62, 702-714.

179. Xiang, Y.; Tang, J.J.; Tao, W.; Cao, X.; Song, B.L.; Zhong, J. Identification of Cholesterol 25-Hydroxylase as a Novel Host Restriction Factor and a Part of the Primary Innate Immune Responses against Hepatitis C Virus Infection. J. Virol. 2015, 89, 6805-6816. [CrossRef] [PubMed]

180. Liu, S.Y.; Aliyari, R.; Chikere, K.; Li, G.; Marsden, M.D.; Smith, J.K.; Pernet, O.; Guo, H.; Nusbaum, R.; Zack, J.A.; et al. Interferon-inducible cholesterol-25-hydroxylase broadly inhibits viral entry by production of 25-hydroxycholesterol. Immunity 2013, 38, 92-105. [CrossRef] [PubMed]

181. Chang, J.; Guo, J.T.; Jiang, D.; Guo, H.; Taylor, J.M.; Block, T.M. Liver-specific microRNA miR-122 enhances the replication of hepatitis C virus in nonhepatic cells. J Virol 2008, 82, 8215-8223. [CrossRef] [PubMed]

182. Narbus, C.M.; Israelow, B.; Sourisseau, M.; Michta, M.L.; Hopcraft, S.E.; Zeiner, G.M.; Evans, M.J. HepG2 cells expressing microRNA miR-122 support the entire hepatitis C virus life cycle. J. Virol. 2011, 85, 12087-12092. [CrossRef] [PubMed]

183. Kambara, H.; Fukuhara, T.; Shiokawa, M.; Ono, C.; Ohara, Y.; Kamitani, W.; Matsuura, Y. Establishment of a novel permissive cell line for the propagation of hepatitis $C$ virus by expression of microRNA miR122. J. Virol. 2012, 86, 1382-1393. [CrossRef] [PubMed]

184. Da Costa, D.; Turek, M.; Felmlee, D.J.; Girardi, E.; Pfeffer, S.; Long, G.; Bartenschlager, R.; Zeisel, M.B.; Baumert, T.F. Reconstitution of the entire hepatitis C virus life cycle in non-hepatic cells. J. Virol. 2012, 86, 11919-11925. [CrossRef] [PubMed]

185. Fukuhara, T.; Kambara, H.; Shiokawa, M.; Ono, C.; Katoh, H.; Morita, E.; Okuzaki, D.; Maehara, Y.; Koike, K.; Matsuura, Y. Expression of microRNA miR-122 facilitates an efficient replication in nonhepatic cells upon infection with hepatitis C virus. J. Virol. 2012, 86, 7918-7933. [CrossRef] [PubMed]

186. Jopling, C.L.; Schutz, S.; Sarnow, P. Position-dependent function for a tandem microRNA miR-122-binding site located in the hepatitis C virus RNA genome. Cell Host Microbe 2008, 4, 77-85. [CrossRef] [PubMed]

187. Masaki, T.; Arend, K.C.; Li, Y.; Yamane, D.; McGivern, D.R.; Kato, T.; Wakita, T.; Moorman, N.J.; Lemon, S.M. miR-122 stimulates hepatitis C virus RNA synthesis by altering the balance of viral RNAs engaged in replication versus translation. Cell Host Microbe 2015, 17, 217-228. [CrossRef] [PubMed]

188. Bandiera, S.; Pfeffer, S.; Baumert, T.F.; Zeisel, M.B. miR-122-A key factor and therapeutic target in liver disease. J. Hepatol. 2015, 62, 448-457. [CrossRef] [PubMed]

189. Gebert, L.F.; Rebhan, M.A.; Crivelli, S.E.; Denzler, R.; Stoffel, M.; Hall, J. Miravirsen (SPC3649) can inhibit the biogenesis of miR-122. Nucl. Acids Res. 2014, 42, 609-621. [CrossRef] [PubMed]

190. Peng, Z.G.; Zhao, Z.Y.; Li, Y.P.; Wang, Y.P.; Hao, L.H.; Fan, B.; Li, Y.H.; Wang, Y.M.; Shan, Y.Q.; Han, Y.X.; et al. Host apolipoprotein B messenger RNA-editing enzyme catalytic polypeptide-like 3G is an innate defensive factor and drug target against hepatitis C virus. Hepatology 2011, 53, 1080-1089. [CrossRef] [PubMed]

191. Zhao, H.; Lin, W.; Kumthip, K.; Cheng, D.; Fusco, D.N.; Hofmann, O.; Jilg, N.; Tai, A.W.; Goto, K.; Zhang, L.; et al. A functional genomic screen reveals novel host genes that mediate interferon-alpha's effects against hepatitis C virus. J. Hepatol. 2012, 56, 326-333. [CrossRef] [PubMed] 
192. Zhu, C.; Xiao, F.; Hong, J.; Wang, K.; Liu, X.; Cai, D.; Fusco, D.N.; Zhao, L.; Jeong, S.W.; Brisac, C.; et al. EFTUD2 Is a Novel Innate Immune Regulator Restricting Hepatitis C Virus Infection through the RIG-I/MDA5 Pathway. J. Virol. 2015, 89, 6608-6618. [CrossRef] [PubMed]

193. Zhu, Y.P.; Peng, Z.G.; Wu, Z.Y.; Li, J.R.; Huang, M.H.; Si, S.Y.; Jiang, J.D. Host APOBEC3G protein inhibits HCV replication through direct binding at NS3. PLoS ONE 2015, 10, e0121608. [CrossRef] [PubMed]

194. Kozlov, M.V.; Kleymenova, A.A.; Romanova, L.I.; Konduktorov, K.A.; Kamarova, K.A.; Smirnova, O.A.; Prassolov, V.S.; Kochetkov, S.N. Pyridine hydroxamic acids are specific anti-HCV agents affecting HDAC6. Bioorg. Med. Chem. Lett. 2015, 25, 2382-2385. [CrossRef] [PubMed]

195. Sato, A.; Saito, Y.; Sugiyama, K.; Sakasegawa, N.; Muramatsu, T.; Fukuda, S.; Yoneya, M.; Kimura, M.; Ebinuma, H.; Hibi, T.; et al. Suppressive effect of the histone deacetylase inhibitor suberoylanilide hydroxamic acid (SAHA) on hepatitis C virus replication. J. Cell. Biochem. 2013, 114, 1987-1996. [CrossRef] [PubMed]

196. Gong, G.; Waris, G.; Tanveer, R.; Siddiqui, A. Human hepatitis C virus NS5A protein alters intracellular calcium levels, induces oxidative stress, and activates STAT-3 and NF-kappa B. Proc. Natl. Acad. Sci. USA 2001, 98, 9599-9604. [CrossRef] [PubMed]

197. Basu, A.; Meyer, K.; Lai, K.K.; Saito, K.; di Bisceglie, A.M.; Grosso, L.E.; Ray, R.B.; Ray, R. Microarray analyses and molecular profiling of Stat3 signaling pathway induced by hepatitis $\mathrm{C}$ virus core protein in human hepatocytes. Virology 2006, 349, 347-358. [CrossRef] [PubMed]

198. McCartney, E.M.; Helbig, K.J.; Narayana, S.K.; Eyre, N.S.; Aloia, A.L.; Beard, M.R. Signal transducer and activator of transcription 3 is a proviral host factor for hepatitis C virus. Hepatology 2013, 58, 1558-1568. [CrossRef] [PubMed]

199. Andre, P.; Komurian-Pradel, F.; Deforges, S.; Perret, M.; Berland, J.L.; Sodoyer, M.; Pol, S.; Brechot, C.; Paranhos-Baccala, G.; Lotteau, V. Characterization of low- and very-low-density hepatitis C virus RNA-containing particles. J. Virol. 2002, 76, 6919-6928. [CrossRef] [PubMed]

200. Popescu, C.I.; Riva, L.; Vlaicu, O.; Farhat, R.; Rouille, Y.; Dubuisson, J. Hepatitis C virus life cycle and lipid metabolism. Biology 2014, 3, 892-921. [CrossRef] [PubMed]

201. Gastaminza, P.; Cheng, G.; Wieland, S.; Zhong, J.; Liao, W.; Chisari, F.V. Cellular determinants of hepatitis C virus assembly, maturation, degradation, and secretion. J. Virol. 2008, 82, 2120-2129. [CrossRef] [PubMed]

202. Pol, A.; Gross, S.P.; Parton, R.G. Review: Biogenesis of the multifunctional lipid droplet: Lipids, proteins, and sites. J. Cell Biol. 2014, 204, 635-646. [CrossRef] [PubMed]

203. Miyanari, Y.; Atsuzawa, K.; Usuda, N.; Watashi, K.; Hishiki, T.; Zayas, M.; Bartenschlager, R.; Wakita, T.; Hijikata, M.; Shimotohno, K. The lipid droplet is an important organelle for hepatitis $\mathrm{C}$ virus production. Nat. Cell Biol. 2007, 9, 1089-1097. [CrossRef] [PubMed]

204. DeVita, R.J.; Pinto, S. Current status of the research and development of diacylglycerol O-acyltransferase 1 (DGAT1) inhibitors. J. Med. Chem. 2013, 56, 9820-9825. [CrossRef] [PubMed]

205. Herker, E.; Harris, C.; Hernandez, C.; Carpentier, A.; Kaehlcke, K.; Rosenberg, A.R.; Farese, R.V., Jr.; Ott, M. Efficient hepatitis $C$ virus particle formation requires diacylglycerol acyltransferase-1. Nat. Med. 2010, 16, 1295-1298. [CrossRef] [PubMed]

206. Menzel, N.; Fischl, W.; Hueging, K.; Bankwitz, D.; Frentzen, A.; Haid, S.; Gentzsch, J.; Kaderali, L.; Bartenschlager, R.; Pietschmann, T. MAP-kinase regulated cytosolic phospholipase A2 activity is essential for production of infectious hepatitis C virus particles. PLoS Pathog. 2012, 8, e1002829. [CrossRef] [PubMed]

207. Zhang, Q.; Gong, R.; Qu, J.; Zhou, Y.; Liu, W.; Chen, M.; Liu, Y.; Zhu, Y.; Wu, J. Activation of the Ras/Raf/MEK pathway facilitates hepatitis $C$ virus replication via attenuation of the interferon-JAK-STAT pathway. J. Virol. 2012, 86, 1544-1554. [CrossRef] [PubMed]

208. Murata, T.; Hijikata, M.; Shimotohno, K. Enhancement of internal ribosome entry site-mediated translation and replication of hepatitis C virus by PD98059. Virology 2005, 340, 105-115. [CrossRef] [PubMed]

209. Ndjomou, J.; Park, I.W.; Liu, Y.; Mayo, L.D.; He, J.J. Up-regulation of hepatitis C virus replication and production by inhibition of MEK/ERK signaling. PLOS ONE 2009, 4, e7498. [CrossRef] [PubMed]

210. Pei, R.; Zhang, X.; Xu, S.; Meng, Z.; Roggendorf, M.; Lu, M.; Chen, X. Regulation of hepatitis C virus replication and gene expression by the MAPK-ERK pathway. Virol. Sin. 2012, 27, 278-285. [CrossRef] [PubMed] 
211. Xu, S.; Pei, R.; Guo, M.; Han, Q.; Lai, J.; Wang, Y.; Wu, C.; Zhou, Y.; Lu, M.; Chen, X. Cytosolic phospholipase A2 gamma is involved in hepatitis C virus replication and assembly. J. Virol. 2012, 86, 13025-13037. [CrossRef] [PubMed]

212. Neveu, G.; Barouch-Bentov, R.; Ziv-Av, A.; Gerber, D.; Jacob, Y.; Einav, S. Identification and targeting of an interaction between a tyrosine motif within hepatitis $C$ virus core protein and AP2M1 essential for viral assembly. PLoS Pathog. 2012, 8, e1002845. [CrossRef] [PubMed]

213. Karaman, M.W.; Herrgard, S.; Treiber, D.K.; Gallant, P.; Atteridge, C.E.; Campbell, B.T.; Chan, K.W.; Ciceri, P.; Davis, M.I.; Edeen, P.T.; et al. A quantitative analysis of kinase inhibitor selectivity. Nat. Biotechnol. 2008, 26, 127-132. [CrossRef] [PubMed]

214. Yamaguchi, A.; Tazuma, S.; Nishioka, T.; Ohishi, W.; Hyogo, H.; Nomura, S.; Chayama, K. Hepatitis C virus core protein modulates fatty acid metabolism and thereby causes lipid accumulation in the liver. Dig. Dis. Sci. 2005, 50, 1361-1371. [CrossRef] [PubMed]

215. Tanaka, N.; Moriya, K.; Kiyosawa, K.; Koike, K.; Gonzalez, F.J.; Aoyama, T. PPARalpha activation is essential for $\mathrm{HCV}$ core protein-induced hepatic steatosis and hepatocellular carcinoma in mice. J. Clin. Investig. 2008, 118, 683-694. [PubMed]

216. Jiang, L.; Gu, Y.; Ye, J.; Liu, F.; Zhao, Y.; Wang, C.; Xu, Y.; Cao, X.; Zhang, L.; Dong, W.; et al. Resveratrol prevents hepatic steatosis induced by hepatitis C virus core protein. Biotechnol. Lett. 2012, 34, 2205-2212. [CrossRef] [PubMed]

217. Singaravelu, R.; Chen, R.; Lyn, R.K.; Jones, D.M.; O’Hara, S.; Rouleau, Y.; Cheng, J.; Srinivasan, P.; Nasheri, N.; Russell, R.S.; et al. Hepatitis C virus induced up-regulation of microRNA-27: A novel mechanism for hepatic steatosis. Hepatology 2014, 59, 98-108. [CrossRef] [PubMed]

218. Appel, N.; Zayas, M.; Miller, S.; Krijnse-Locker, J.; Schaller, T.; Friebe, P.; Kallis, S.; Engel, U.; Bartenschlager, R. Essential role of domain III of nonstructural protein 5A for hepatitis C virus infectious particle assembly. PLoS Pathog. 2008, 4, e1000035. [CrossRef] [PubMed]

219. Masaki, T.; Suzuki, R.; Murakami, K.; Aizaki, H.; Ishii, K.; Murayama, A.; Date, T.; Matsuura, Y.; Miyamura, T.; Wakita, T.; et al. Interaction of hepatitis C virus nonstructural protein 5A with core protein is critical for the production of infectious virus particles. J. Virol. 2008, 82, 7964-7976. [CrossRef] [PubMed]

220. Camus, G.; Herker, E.; Modi, A.A.; Haas, J.T.; Ramage, H.R.; Farese, R.V., Jr.; Ott, M. Diacylglycerol acyltransferase-1 localizes hepatitis $C$ virus NS5A protein to lipid droplets and enhances NS5A interaction with the viral capsid core. J. Biol. Chem. 2013, 288, 9915-9923. [CrossRef] [PubMed]

221. Tellinghuisen, T.L.; Foss, K.L.; Treadaway, J. Regulation of hepatitis C virion production via phosphorylation of the NS5A protein. PLoS Pathog. 2008, 4, e1000032. [CrossRef] [PubMed]

222. Masaki, T.; Matsunaga, S.; Takahashi, H.; Nakashima, K.; Kimura, Y.; Ito, M.; Matsuda, M.; Murayama, A.; Kato, T.; Hirano, H.; et al. Involvement of hepatitis C virus NS5A hyperphosphorylation mediated by casein kinase I-alpha in infectious virus production. J. Virol. 2014, 88, 7541-7555. [CrossRef] [PubMed]

223. Kim, S.; Jin, B.; Choi, S.H.; Han, K.H.; Ahn, S.H. Casein kinase II inhibitor enhances production of infectious genotype 1a hepatitis C virus (H77S). PLoS ONE 2014, 9, e113938. [CrossRef] [PubMed]

224. Siddiqui-Jain, A.; Drygin, D.; Streiner, N.; Chua, P.; Pierre, F.; O’Brien, S.E.; Bliesath, J.; Omori, M.; Huser, N.; Ho, C.; et al. CX-4945, an orally bioavailable selective inhibitor of protein kinase CK2, inhibits prosurvival and angiogenic signaling and exhibits antitumor efficacy. Cancer Res. 2010, 70, 10288-10298. [CrossRef] [PubMed]

225. Huang, H.; Sun, F.; Owen, D.M.; Li, W.; Chen, Y.; Gale, M., Jr.; Ye, J. Hepatitis C virus production by human hepatocytes dependent on assembly and secretion of very low-density lipoproteins. Proc. Natl. Acad. Sci. USA 2007, 104, 5848-5853. [CrossRef] [PubMed]

226. Tiwari, S.; Siddiqi, S.A. Intracellular trafficking and secretion of VLDL. Arterioscler. Thromb. Vasc. Biol. 2012, 32, 1079-1086. [CrossRef] [PubMed]

227. Long, G.; Hiet, M.S.; Windisch, M.P.; Lee, J.Y.; Lohmann, V.; Bartenschlager, R. Mouse hepatic cells support assembly of infectious hepatitis C virus particles. Gastroenterology 2011, 141, 1057-1066. [CrossRef] [PubMed]

228. Benga, W.J.; Krieger, S.E.; Dimitrova, M.; Zeisel, M.B.; Parnot, M.; Lupberger, J.; Hildt, E.; Luo, G.; McLauchlan, J.; Baumert, T.F.; et al. Apolipoprotein E interacts with hepatitis $C$ virus nonstructural protein 5A and determines assembly of infectious particles. Hepatology 2010, 51, 43-53. [CrossRef] [PubMed] 
229. Cun, W.; Jiang, J.; Luo, G. The C-terminal alpha-helix domain of apolipoprotein E is required for interaction with nonstructural protein 5A and assembly of hepatitis C virus. J. Virol. 2010, 84, 11532-11541. [CrossRef] [PubMed]

230. Boyer, A.; Dumans, A.; Beaumont, E.; Etienne, L.; Roingeard, P.; Meunier, J.C. The association of hepatitis $\mathrm{C}$ virus glycoproteins with apolipoproteins $\mathrm{E}$ and $\mathrm{B}$ early in assembly is conserved in lipoviral particles. J. Biol. Chem. 2014, 289, 18904-18913. [CrossRef] [PubMed]

231. Lee, J.Y.; Acosta, E.G.; Stoeck, I.K.; Long, G.; Hiet, M.S.; Mueller, B.; Fackler, O.T.; Kallis, S.; Bartenschlager, R. Apolipoprotein E likely contributes to a maturation step of infectious hepatitis $C$ virus particles and interacts with viral envelope glycoproteins. J. Virol. 2014, 88, 12422-12437. [CrossRef] [PubMed]

232. Coller, K.E.; Heaton, N.S.; Berger, K.L.; Cooper, J.D.; Saunders, J.L.; Randall, G. Molecular determinants and dynamics of hepatitis C virus secretion. PLoS Pathog. 2012, 8, e1002466. [CrossRef] [PubMed]

233. Cheng, Y.L.; Lan, K.H.; Lee, W.P.; Tseng, S.H.; Hung, L.R.; Lin, H.C.; Lee, F.Y.; Lee, S.D. Amiodarone inhibits the entry and assembly steps of hepatitis C virus life cycle. Clin. Sci. 2013, 125, 439-448. [CrossRef] [PubMed]

234. Raval, S.K.; Raval, P.S.; Jain, M.R. Emerging therapies for dyslipidemia: Known knowns and known unknowns of MTP inhibitors. Recent Pat. Endocr. Metab. Immune Drug Discov. 2012, 6, 24-29. [CrossRef] [PubMed]

235. Li, X.; Jiang, H.; Qu, L.; Yao, W.; Cai, H.; Chen, L.; Peng, T. Hepatocyte nuclear factor 4alpha and downstream secreted phospholipase A2 GXIIB regulate production of infectious hepatitis C virus. J. Virol. 2014, 88, 612-627. [CrossRef] [PubMed]

236. Anderson, L.J.; Lin, K.; Compton, T.; Wiedmann, B. Inhibition of cyclophilins alters lipid trafficking and blocks hepatitis C virus secretion. Virol. J. 2011, 8, 329. [CrossRef] [PubMed]

237. Peng, Z.G.; Fan, B.; Du, N.N.; Wang, Y.P.; Gao, L.M.; Li, Y.H.; Liu, F.; You, X.F.; Han, Y.X.; Zhao, Z.Y.; et al. Small molecular compounds that inhibit hepatitis $C$ virus replication through destabilizing heat shock cognate 70 messenger RNA. Hepatology 2010, 52, 845-853. [CrossRef] [PubMed]

238. Chen, D.Z.; Jiang, J.D.; Zhang, K.Q.; He, H.P.; Di, Y.T.; Zhang, Y.; Cai, J.Y.; Wang, L.; Li, S.L.; Yi, P.; et al. Evaluation of anti-HCV activity and SAR study of (+)-lycoricidine through targeting of host heat-stress cognate 70 (Hsc70). Bioorg. Med. Chem. Lett. 2013, 23, 2679-2682. [CrossRef] [PubMed]

239. Du, N.N.; Peng, Z.G.; Bi, C.W.; Tang, S.; Li, Y.H.; Li, J.R.; Zhu, Y.P.; Zhang, J.P.; Wang, Y.X.; Jiang, J.D.; et al . $\mathrm{N}$-substituted benzyl matrinic acid derivatives inhibit hepatitis $\mathrm{C}$ virus (HCV) replication through down-regulating host heat-stress cognate 70 (Hsc70) expression. PLoS ONE 2013, 8, e58675. [CrossRef] [PubMed]

240. Chen, D.; Cai, J.; Yin, J.; Jiang, J.; Jing, C.; Zhu, Y.; Cheng, J.; Di, Y.; Zhang, Y.; Cao, M.; et al. Lycorine-derived phenanthridine downregulators of host Hsc70 as potential hepatitis C virus inhibitors. Future Med. Chem. 2015, 7, 561-570. [CrossRef] [PubMed]

241. Parent, R.; Qu, X.; Petit, M.A.; Beretta, L. The heat shock cognate protein 70 is associated with hepatitis C virus particles and modulates virus infectivity. Hepatology 2009, 49, 1798-1809. [CrossRef] [PubMed]

242. Lavie, M.; Goffard, A.; Dubuisson, J. Assembly of a functional HCV glycoprotein heterodimer. Curr. Issues Mol. Biol. 2007, 9, 71-86. [PubMed]

243. Soriano, V.; Vispo, E.; Poveda, E.; Labarga, P.; Barreiro, P. Treatment failure with new hepatitis C drugs. Expert Opin. Pharmacother. 2012, 13, 313-323. [CrossRef] [PubMed]

244. Tong, X.; le Pogam, S.; Li, L.; Haines, K.; Piso, K.; Baronas, V.; Yan, J.M.; So, S.S.; Klumpp, K.; Najera, I. In vivo emergence of a novel mutant L159F/L320F in the NS5B polymerase confers low-level resistance to the HCV polymerase inhibitors mericitabine and sofosbuvir. J. Infect. Dis. 2014, 209, 668-675. [CrossRef] [PubMed]

245. Donaldson, E.F.; Harrington, P.R.; O'Rear, J.J.; Naeger, L.K. Clinical evidence and bioinformatics characterization of potential hepatitis C virus resistance pathways for sofosbuvir. Hepatology 2015, 61, 56-65. [CrossRef] [PubMed]

246. Bush, C.O.; Greenstein, A.E.; Delaney, W.E.T.; Beran, R.K. Hepatitis C viral entry inhibitors prolong viral suppression by replication inhibitors in persistently-infected Huh7 cultures. PLoS ONE 2013, 8, e65273. [CrossRef] [PubMed] 
247. Xiao, F.; Fofana, I.; Heydmann, L.; Barth, H.; Soulier, E.; Habersetzer, F.; Doffoel, M.; Bukh, J.; Patel, A.H.; Zeisel, M.B.; et al. Hepatitis C virus cell-cell transmission and resistance to direct-acting antiviral agents. PLoS Pathog. 2014, 10, e1004128. [CrossRef] [PubMed]

248. Lanford, R.E.; Hildebrandt-Eriksen, E.S.; Petri, A.; Persson, R.; Lindow, M.; Munk, M.E.; Kauppinen, S.; Orum, H. Therapeutic silencing of microRNA-122 in primates with chronic hepatitis $\mathrm{C}$ virus infection. Science 2010, 327, 198-201. [CrossRef] [PubMed]

249. Puyang, X.; Poulin, D.L.; Mathy, J.E.; Anderson, L.J.; Ma, S.; Fang, Z.; Zhu, S.; Lin, K.; Fujimoto, R.; Compton, T.; et al. Mechanism of resistance of hepatitis $\mathrm{C}$ virus replicons to structurally distinct cyclophilin inhibitors. Antimicrob. Agents Chemother. 2010, 54, 1981-1987. [CrossRef] [PubMed]

250. Coelmont, L.; Hanoulle, X.; Chatterji, U.; Berger, C.; Snoeck, J.; Bobardt, M.; Lim, P.; Vliegen, I.; Paeshuyse, J.; Vuagniaux, G.; et al. DEB025 (Alisporivir) inhibits hepatitis C virus replication by preventing a cyclophilin A induced cis-trans isomerisation in domain II of NS5A. PLoS ONE 2010, 5, e13687. [CrossRef] [PubMed]

251. Garcia-Rivera, J.A.; Bobardt, M.; Chatterji, U.; Hopkins, S.; Gregory, M.A.; Wilkinson, B.; Lin, K.; Gallay, P.A. Multiple mutations in hepatitis C virus NS5A domain II are required to confer a significant level of resistance to alisporivir. Antimicrob. Agents Chemother. 2012, 56, 5113-5121. [CrossRef] [PubMed]

252. Lim, P.J.; Gallay, P.A. Hepatitis C NS5A protein: Two drug targets within the same protein with different mechanisms of resistance. Curr. Opin. Virol. 2014, 8, 30-37. [CrossRef] [PubMed]

253. Israelow, B.; Mullokandov, G.; Agudo, J.; Sourisseau, M.; Bashir, A.; Maldonado, A.Y.; Dar, A.C.; Brown, B.D.; Evans, M.J. Hepatitis C virus genetics affects miR-122 requirements and response to miR-122 inhibitors. Nat. Commun. 2014, 5, 5408. [CrossRef] [PubMed]

254. Colpitts, C.C.; Zeisel, M.B.; Baumert, T.F. When one receptor closes, another opens: Claudins and the hepatitis C virus E1 glycoprotein. Hepatology 2015. [CrossRef] [PubMed]

(C) 2015 by the authors; licensee MDPI, Basel, Switzerland. This article is an open access article distributed under the terms and conditions of the Creative Commons by Attribution (CC-BY) license (http:/ / creativecommons.org/licenses/by/4.0/). 